\title{
Impact of geomorphometric parameters on landslide occurrence and distribution in Yamuna River Basin, North-Western Himalaya, India
}

\section{Ravi Shankar}

CIMFR: Central Institute of Mining and Fuel Research CSIR

Gyan Prakash Satyam ( $\sim$ gyanpsatyam@gmail.com )

IIT INDIAN SCHOOL OF MINES Dhanbad

\section{Prakash Kumar Singh}

Allahabad University: University of Allahabad

\section{Ranjeet Kumar Paswan}

CIMFR: Central Institute of Mining and Fuel Research CSIR

\section{Research Article}

Keywords: Morphotectonic indices, Landslides, Yamuna river basin, DEM

Posted Date: April 19th, 2021

DOI: https://doi.org/10.21203/rs.3.rs-404865/v1

License: (c) (i) This work is licensed under a Creative Commons Attribution 4.0 International License. Read Full License 


\section{Abstract}

Landscape evolution is a dynamic process controlled by several geomorphic parameters along with geology, tectonics and climatic condition of the area. The Himalayan mountain belt is highly geodynamic with immature topography which offer one of the best places to study the impact of geomorphotectonic characteristics on the occurrence and distribution of landslides along with tectonically modified geomorphic features. The morphotectonic study of the drainage basin is extensively utilized to analyze the landscape evolution in the study area along with impact of neotectonic activity in landscape evolution. The study shows that the Yamuna River, originating from the mighty Himalayas, flows downslope by adjusting its course due to ongoing tectonic activities, underlying structures, and climatic factors. Active tectonics play important role in modifying the landscape and impacting the occurrence and distribution of landslides. The characteristics of rainfall induced landslides have been studied in relation to morphotectonic parameters. The analysis shows that the probability density of landslides was highest in the range of $25^{\circ}-30^{\circ}$ and that landslide size increased up to $20^{\circ}-25^{\circ}$ slope angle, decreasing on further increase in slope angle. The study also shows that slope angle merely controls number of landslides rather than size of the landslides. Landslides were mostly restricted to South facing slopes. About $91 \%$ of the landslide occur in the drainage density range of 1.2 to $2.1 \mathrm{~km} / \mathrm{km}^{2}$ while landslides show very low occurrence in either lower $(<1.2)$ or higher $(>2.1)$ drainage density. The present analysis can be very helpful in landslide risk reduction and landslide hazard zonation and probably to plan critical locations for installation of early warning signals.

\section{Introduction}

Landscape evolution is a dynamic process controlled by several geomorphic parameters along with geology, tectonics and climatic condition of the area (Bishop 2013). They are very sensitive to natural and artificial infringement such as a tectonic event, rainfall and earthquake in addition to anthropogenic activities that disturb the natural progression of erosional episodes and, in the process, creates large number of landforms (Sharp 1982). Landslide is the result of these erosional episodes and their occurrence and distribution are interrelated with the geomorphometric parameters such as relief, slope, slope direction, drainage basin etc. along with an associated natural or anthropogenic event (Korup 2005; Cerri 2018). Thus, identification of right parameters controlling landslide distribution in an area is of prime importance.

In very simple terms, a landslide is the movement of the rock mass, earth, or debris down a slope (Cruden 1991). It is a very complex phenomenon and can be easily characterized as one of the most devastating erosional processes in mountainous areas (Bennett et al. 2012). In particular, rainfall-induced landslides occur almost every year worldwide ( $\mathrm{Li}$ et al. 2011). Landslides are associated with the transportation of large volume of material and have continuously led to the evolution of the landscapes through a variety of slope movement processes such as flows, slides, falls, topples, spread, and other complex types (Varnes 1978; Cruden and Varnes 1996; Hungr et al. 2014). A triggering event such as rainfall, earthquake, 
snowmelt is commonly associated with a landslide (Guthrie and Evans 2004; Malamud et al. 2004; Guzzetti et al. 2009; Florsheim and Nichols 2013; Tanyas et al. 2019).

In addition, the neotectonic activities also play a key role in the development of modern landform through deformation in the lithospheric crust (Rana et al. 2016). The preexisting drainage networks and consequently the drainage basin is very much sensitive, and are the first element that responds to sudden geomorphic change, resulting from ongoing tectonic activities (Goldsworthy \& Jackson, 2000, Queiroz et al., 2015). The evolution of geomorphic architecture resulting from neotectonic activities in a region can also be effectively assessed through the morphotectonic analysis (Das and Gupta, 2019). Nowadays, the GIS technologies in association with field investigations have the potential to provide synoptic view and multi-temporal data of a drainage basin (Rai et al., 2017).

The Himalaya is amongst the youngest mountain chains in the world and geodynamically active in nature exhibiting complex geological settings and immature topography (Awasthi and Prakash, 2001, Valdiya, 2016). Therefore, the Himalayan region offer one of the best places to study the impact of geomorphotectonic characteristics on the occurrence and distribution of landslides along with tectonically modified geomorphic features. In this study, an attempt has been made to assess the geomorphometric characteristics of the Yamuna river basin, North Western Himalaya, India and further identification of causative factors responsible for large number of landslide associated with rainfall event (Fig. 1).

\section{Regional Setting}

The basin mainly constitutes parts of Higher Himalaya, Lesser Himalaya, Siwalik Group of rocks, as well as the foreland basin. The extreme northeastern portion of the basin depicts lithologies of Higher Himalaya (Vaikrita Group) which is strongly metamorphosed in nature. The Main Central Thrust (MCT) marks the southern limit of the Higher Himalaya litho-unit. In the present study area, the MCT zone is confined between the Vaikrita Thrust (VT) in the north and the Munsiari Thrust (MT) in the south (Yin, 2006). Further, the Munsiari Almora nappe is also sandwiched between Vaikrita Thrust in the north and Munsiari Thrust (MT) in the south and formed due to tectonic transport of the rocks from Higher Himalaya to the Lesser Himalaya over the Main Central Thrust during Eocene-Oligocene (Ahmad et al.,2000). The Munsiari Almora nappe is the largest nappes distributed along the Himalayan arc. The Munsiari Thrust is a highly tectonised and significantly condensed litho-unit representing the root zone of the Lesser Himalayan crystalline nappes (Kumar, 2016). Due to the lithological and petrological similarity of Munsiari and Almora Formations, Valdiya (1980), refers to them as the same litho-stratigraphic unit. The Ramgarh Group of rocks are present as a klippe and exposed in imbrication under the Munsiari Almora nappe in the basin. After the Munsiari Thrust, there lies a thick pile of unmetamorphosed to lowgrade metamorphosed Proterozoic metasedimentary litho-unit of the Lesser Himalayan (LH) zone. The Ton Thrust (TT) striking over $100 \mathrm{~km}$, divides this region into the Inner (older) and Outer (younger) Lesser Himalayan litho-units at the western edge of the Munsiari Almora Nappes. The base of the Inner Lesser 
The Outer Lesser Himalaya is comprised of $850 \mathrm{Ma}$ Chandpur Formation. The Main Boundary Thrust (MBT) marks the southern limit of Lesser Himalaya. The variation in geomorphological, geological, and geophysical signature along the Main Boundary Thrust suggests the active nature of the thrust (Valdiya, et al., 1984) After MBT; rocks of the Siwalik Formation are deposited and runs almost parallel to the Lesser Himalaya (LH). The rocks of the Siwalik Formation have been formed by the deposition of sediments by ancient Himalayan rivers during the last $16 \mathrm{Ma}$ to $1.5 \mathrm{Ma}$ (Valdiya, 2010). The Main Frontal Thrust (MFT) is situated at the southern boundary of Siwalik rocks and followed by the foreland basin. The foreland basin has been formed by the flexure of the Indian plate through the weight of Himalaya Mountain. The foreland basin is comprised of a thick cover $(\sim 6 \mathrm{~km})$ of quaternary sediments deposited over the Paleozoic basement platform. The detailed regional setting has been shown in Fig. 2.

\section{Materials And Methods}

The ongoing collisional event between the Indian and Eurasian plate has resulted in tremendous stress generation and tectonic activities in the Himalayan zone. The Himalaya is considered as one of the youngest and dynamic mountain belt in the world. Due to enduring stress generation geomorphological characteristics of Himalayan basins keeps on modifying within short span of time. Keeping this in view, the methodology of present study has been sub-divided into three parts which includes (1) Assessment of geomorphological parameter of the basin; (2) Evaluation of Neotectonic impacts on the assessed geomorphological parameters and, (3) Statistical analysis of associated landslide

\subsection{Geomorphological Parameters}

The geomorphological characteristics have been evaluated utilizing the Advanced Spaceborne Thermal Emission and Reflection Radiometer Digital Elevation Map (ASTER DEM) of the basin having a spatial resolution of $30 \mathrm{~m}$. The ASTER-DEM has been processed in the GIS environment using ARC GIS v.10.2. The drainage basin has been extracted using Arc-hydro tool and further processed to extract drainage network map, slope map, aspect map, drainage density map. In addition, some important basin geometry viz., Form Factor (Ff) and Circulatory ratio (Rc) have also been calculated for the Yamuna River basin.

\subsection{Impact of Neotectonics}

The impact of Neotectonics on the evaluated geomorphological parameters have been assessed with the help of different geomorphic indices. The geomorphic indices of the basin are calibrated with the help of different tools such as Valley morph tool and 3D Analyst tool that works on GIS platform. Further, some calculations have been carried in the Global Mapper-13 software package. The significant geomorphic indices mainly comprised of Stream Length-Gradient Index (SL), Asymmetry factor (AF), Transverse Topography Symmetry (T), Mountain Front Sinuosity (Smf). The indices have been briefly discussed below and their mathematical expressions are presented in Table 2. The indices have been calculated for ten 5th order sub-basins which covers the maximum part of the Yamuna basin in the study area. 
The Stream gradient index is one of the indices to evaluate active tectonics concerning the shape of stream channels (Hack, 1973). The higher value of this index indicates that the river is flowing over active uplift or resistant lithology whereas, the lower value indicates stream flowing parallel to the crushed zones due to strike-slip faulting (Keller and Printer, 2002). Therefore, the anomaly in SL value indicates activities of geological structures that disrupt the bedrock (Guarnieri and Pirrotta, 2007). The active vertical uplift gives rise to sharp knick points in the river longitudinal profile. In the present study, the main streams of each 5th order drainage sub-basins are segmented at succeeding equal contour intervals to measure the elevation difference. The calculated SL distribution patterns are analyzed along with the longitudinal profile of the river to understand the lithological and tectonic interactions.

\subsubsection{Asymmetry factor (AF)}

The drainage basin asymmetry factor is helpful in identifying the neotectonic activity by determining the asymmetry and the lateral tilting nature of drainage basins concerning the main river course. The tilting may be linked with the activity of active fault in the basin (Hare and Gardner, 1985; Cox, 1994). Therefore, the Value of AF tells about the asymmetry of the basin and the influence of active tectonics or lithological control. It is a ratio of the basin area laying on the right (Facing downstream) to the total area of the drainage basin.

\subsubsection{Transverse Topography Symmetry (T)}

The Transverse Topography Symmetry is a very significant quantitative parameter for evaluating tectonic tilt of the basin resulting from active tectonics. The variation in this index indicates differential upliftment rates in basins. These upliftment causes by active tectonics lead to the change in channel slope and consequently shift in the river channel (Jain and Sinha, 2005). This factor varies within the range of 0 (minimum tilting) to 1 (maximum tilting). The Valley morph tool under Arc-GIS environment (After Dexaberger et al., 2014) have been processed and the measurements were taken at the interval of every $150 \mathrm{~m}$. Further, the mean value of $\mathrm{T}$ has been obtained from the several values of $\mathrm{T}$ calculated from the Valleymorph tool.

\subsubsection{The Mountain Front Sinuosity (Smf)}

The index of mountain front sinuosity (Smf) is used to determine the degree of active tectonics in a mountainous region. The Sinuosity of the mountain front (Smf) can be described as the ratio of the mountain front's length along the mountain foot which is also known as the break-in topography of the slope (Lmf) and the mountain front extension along a straight line (Ls) (after Bull, 1978). This index indicates the relationship between the behavior of rivers (erosive process) to produce an irregular front and vertical tectonic activity to produce a straight front on the mountain (Bull and McFadden, 1977, Keller, 1986). If the ratio of this index is equal to 1 , it indicates the activity of geotectonic processes and the young nature of mountains, and the increase of this value indicates lesser tectonic activities and the dominance of surface processes (Rockwell et al., 1985; Keller, 1986; Silva et al., 2003). The increase in Smf value indicates a reduced upliftment rate resulting from active tectonics and the predominance of 
fronts. The data for Smf has been calculated at an interval of 500 meters in the basin from the lowest point up to an elevation of $5882 \mathrm{~m}$

\subsection{Landslide characteristics}

For the landslide study in the region, landslide inventory was prepared from the available data on the Geological Survey of India Website (BHUKOSH). The downloaded data have been processed in a GIS environment and statistically analyzed (Table.1). It is well understood that the large-scale landslide is the most hazardous but a small-scale landslide event is very common therefore quantification of the frequency size distribution for landslides is important to assess landslide hazard and also for future land use planning (Malamud et al. 2004; Hurst et al. 2013). A large number of literature is available on the magnitude of area and volume of the landslide, all suggesting area of landslide may vary up to 8 orders of magnitude and volume around 12 orders of magnitude (Malamud et al. 2004; Guzzetti et al. 2009). To quantify the occurrence of the landslide in a particular area, frequency-size statistical analysis is generally performed on a large number of landslide data from landslide inventory. The probability density $\left(P_{D}\right)$ of the total number of landslides in this study is estimated following Malamud et al. (2004) using Equation. 1.

$$
P_{D}=\frac{1}{N_{L}} \frac{\delta N}{\delta A_{L}}
$$

1

Where, $\delta N$ is the total number of landslides with areas between $A_{L}$ and $A_{L}+\delta A_{L}$, and $N_{L}$ is the total number of landslides in the inventory. The bin size is adjusted in such a way that bin width $\left(\delta A_{L}, \mathrm{~km}^{2}\right)$ varies in log scale.

It is interesting to note that despite large variations in landslide types, sizes, distribution, geology, and triggering mechanisms, evidence indicates that in many historical and fresh landslides, the frequencyarea distribution (FAD) of medium and large scale landslide decays following inverse power law of landslide area (Hovius et al. 1997; Stark and Hovius 2001; Guzzetti et al. 2002, 2009; Guthrie and Evans 2004; Malamud et al. 2004; Eeckhaut et al. 2007; Hurst et al. 2013). Experience from FAD plots of a large number of researches carried around the world suggests that two scaling regimes exist; an inverse power law exists only for landslide greater than a particular size and the minimum size will vary for different inventories, frequency of small landslide generally follow a positive power law. The transition from one to other is referred to as rollover by many researchers which can also be marked by the peak point of the FAD after which frequency density curve starts to decrease following positive power law (Guthrie and Evans 2004; Eeckhaut et al. 2007; Hurst et al. 2013; Tanyas et al. 2019). Many researchers believe that a rollover occurs in FAD of historical inventories where evidence of smaller landslide has been lost due to subsequent modification in the landscape by landslides, erosion, vegetation growth, anthropogenic influence, etc. (Malamud et al. 2004; Eeckhaut et al. 2007; Hurst et al. 2013). The point in FAD where the 
curve begins to diverge has been referred to as cut-off point, visible in both cumulative and noncumulative FAD (Hovius et al. 1997; Stark and Hovius 2001; Tanyas et al. 2019).

\section{Results And Discussion}

\subsection{Geomorphological Parameters}

The Yamuna river basin in the study area is mainly a 7th order drainage basin exhibiting sub-dendritic, trellis, and rectangular types of drainage patterns (Fig. 3). Along with these, the drainage pattern also shows sharp bending of the stream channel and channel straightening at places. These drainage patterns indicate that the basin is under several kinds of control, which mainly includes structural, topographic, and lithological. The drainage density map of the Yamuna river basin illustrates very low (<1 $\mathrm{km} / \mathrm{sq} \mathrm{km}$ ) to low (<1.9 km/sq km) in a majority of the upper portion of the basin (Fig. 4). Whereas, moderate $(2-2.8 \mathrm{~km} / \mathrm{sq} \mathrm{km})$ to relatively higher drainage density $(2.9-3.6 \mathrm{~km} / \mathrm{sq} \mathrm{km})$ is chiefly located in the lower part of the basin (Fig. 4). The drainage density is greatly influenced by rainfall intensity, rock resistivity, mean annual runoff, and landslides, in many cases (Chorley 1957a, b; Chorley and Morgan 1962, Morisawa 1962, Zavoianu 1985; Gardiner 1996). The parameter bears inverse relation with infiltration capacity of the basin, permeability of the subsoil, degree of development of drainage network, texture, and stream within the basin (Horton 1945, Strahler 1956, Melton 1957, Zavoianu 1985). The drainage density significantly affects the runoff pattern in a basin as the surface runoffs are removed rapidly in a region having higher drainage density (Chorley 1969). The lower drainage density in the present study attributes to the low mean annual runoff, higher infiltration capacity or permeability of subbasin, higher vegetation cover, and well-drained soil. Hasegawa et al, (2013) suggested that the basin having lower drainage density are prone to large-scale landslide whereas moderate to higher drainage density attributes to shallow seated landslide events. Smallest landslides seem to be concentrated in the drainage density range below $2.2 \mathrm{~km}$ per square $\mathrm{km}$. The median landslide size is almost equal for drainage density till $2.2 \mathrm{~km}$ per square $\mathrm{km}$ but increases beyond this value. Some of the largest landslides albeit few in number are concentrated in the drainage density range of 2.2 to $2.5 \mathrm{~km}$ per square $\mathrm{km}$. Interestingly, larger landslides are also concentrated in the drainage density range of 1 to $2.2 \mathrm{~km}$ per square km (Fig. 5). The data of recent landslide events, when studied along with the drainage density map of the basin, supports the finding of Hasegawa et al, (2013). Almost all the landslide events are characteristically confined to the region having lower drainage density $(0.16 \mathrm{~km} / \mathrm{sq} \mathrm{km}$ to $1.9 \mathrm{~km} / \mathrm{sq} \mathrm{km})$. The Form Factor of the sub-basins ranges from 0.2 (sub-basins " $E$ " and " $G$ ") to 0.53 for sub-basin " $D$ ”. Amongst another watershed, the moderate value of form factor $(0.25<$ form factor $<0.4)$ have been observed as 0.29 for sub-basins " $F$ " 0.29 for sub-basin "J" 0.32 for sub-basin " $A$ "; 0.39 for sub-basin "B". The higher value ( $>0.4$ ) of form factor has been observed as; 0.41 for sub-basin "I" 0.48 for sub-basin " $C$ " and 0.50 for sub-basin " $\mathrm{H}$ " (classification after Prabhakaran and Raj, 2018). The Form Factor is mainly controlled by drainage development in a basin because of neotectonic activities. In the initial phase of basin development, the tectonically undisturbed basins are pear-shaped which becomes elongated under the influence of active tectonics and continuous erosion (Prabhakaran et al., 2018). It varies between 0 (hirhlv elnnnated) tn 1(nirnular) The Form Factor attributes to the peak discharge (Sreedevi, 2005) and Loading [MathJax]/jax/output/CommonHTML/jax.js

Page $7 / 33$ 
flow intensity (Mesa, 2006) of the drainage network. The observation suggests that the majority of the drainage basin has a moderate to low form factor. This observation advocates that almost all sub-basins of the Yamuna river basin is elongated in shape having lower peak flow of longer duration. The circulatory ratio generally varies from 0 to 1 . In present study, the Circulatory ratio of the sub-basins ranges from 0.16 (for sub-basins " $G$ ") to 0.53 for sub-basin " $D$ ". The other sub-basins possesses low to a moderate value of Circulatory ratio, which "comprises 0.26 for sub-basin " $E$ ", 0.27 for sub-basin " $F$ ", 0.31 for sub-basin "A", 0.32 for sub-basin "J", 0.36 for sub-basin "I", 0.38 for sub-basin "B", 0.42 for sub-basin " $\mathrm{C}$ ", and 0.46 for sub-basin " $\mathrm{H}$ ". The circulatory ratio is largely influenced by basin slope, basin relief, structural features, stream length, etc. The ratio significantly indicates different stages of the life cycle of the sub-basin (Wilson et al. 2012). In present context, the circulatory ratio for sub-basins indicates the youth stage of the tributaries with moderately to strongly elongated sub-basin. The characteristics of low runoff of the basin facilitate the higher infiltration rate of water, which further makes the subsoil permeable.

\subsection{Impact of Neotectonics}

The river longitudinal profile for fifth-order streams of all sub-basins is observed to be the concave upward pattern which suggests tectonic instability in the region since the river profiles tend to be more strongly concave in tectonically active regions resulting from tectonically induced spatial variations in uplift rates (Kale and Shejwalkar, 2008; Seybold et al., 2020). The calculated SL index curve for all the fifth-order sub-basins when plotted with the longitudinal profile of the river presents a remarkable feature of the basin. The SL index shows characteristic higher values, steep rise and intersection with the river longitudinal profile, in the region, where it encounters active faults which indicate tectonic control on the river development (sub-basins, $5 \mathrm{~A}, \mathrm{~B}, \mathrm{E}, \mathrm{J}$ ). The major thrust like MBT, Munsiari thrust, Bearing thrust, Ton thrust is passing through the river profile have higher SL index values (Fig. 6). The SL index and curve exhibit characteristics lower values for those sub-basins where stream channels are not traversed by major faults. Further, minor fluctuations in the SL profiles also indicate recent active tectonics in the subbasins (Ramírez-Herrera and Gaidzik 2017; Shankar et al., 2020). The observed SL index for different subbasins indicates the characteristic increase in landslide events (in terms of frequency and area) with increase in SL anomaly. Similar observations have also been made by different researchers (viz., Hack, 1973; Troiani, 2014) while working in different neotectonically active region. This may be because of the fact that the vertical upliftment of sub-basins accelerates river incision producing over-steepened and unstable slopes, which enhances the landslide activities. The Asymmetry factors measured in our study ranged from 23 for sub-basin " $F$ " to 64 for sub-basin "D" (Fig. 7) in which the AF > 50 indicates a tectonic tilt of the sub-basin towards left (viewing towards downstream side of the sub-basin) and therefore depicting the upliftment in the opposite direction. The observation suggests that almost all the subbasins are tilted towards their left bank (viewing downstream) and hence uplifted in their right bank. The average values of Transverse Topography symmetry of the sub-basins range from 0.17 (in case of subbasin $\mathrm{C}$ ) to a maximum of 0.58 (for sub-basin $\mathrm{F}$ ). The values of $\mathrm{T}$ is also supporting the results of $\mathrm{AF}$ values. The streams in all the sub-basin show remarkable shifting in the opposite direction of the 
the basin ranges from (1.02) in case of sub-basin e to maximum of (2.63) at some localities of sub-basin and average of (1.53) suggesting Active Mountain fronts for all the sub-basins (Fig. 8). The calculated Smf values of the sub-basins showing an active mountain front. In addition to these observations, various neotectonic structures such as sand dykes, lenses, triangular fault faces, and knick-points have been observed at an outcrop scale at different locations in the basin during the field investigations (Fig. 9).

\subsection{Landslide Analysis}

The hill slope is an important controlling factor for mass wasting processes (Larsen and Torres-sanchez 1998). From our general understanding of Mohr-Coulomb failure theory, shear stress of the mass has a direct relation to slope angle, which essentially means that more the slope angle more will be shear stress available for failure. In this regard, landslides can be expected on relatively steeper slopes. In this study, landslides originated on a wide range of slope angles however, the majority seems to have concentrated in the slope range of $40^{\circ}-70^{\circ}$ (Fig. 10). The percentage of the landslide ( 78\%) tends to increase with slope angle with a maximum in the range $50^{\circ}-70^{\circ}$. Few landslides $(\sim 11 \%)$ were recorded on very gentle slopes $\left(\leq 30^{\circ}\right)$ while the frequency of landslide $(2 \%)$ decays significantly towards a higher slope angle of $\geq 70^{\circ}$ (Fig. 11). Florsheim and Nichols (2013) analyzed shallow translational rainfall triggered historical landslides and concluded that the majority of the slides initiated on an average slope of $\sim 22^{\circ}$. Martin et al. (2002) analyzing shallow landslides highlights that most landslides tend to initiate on hill slopes of $25^{\circ}-30^{\circ}$. The analyzed inventory in the present case is not limited to shallow landslides and therefore it becomes difficult to get similar threshold values. Shallow landslide such as debris slide and flow typically occurs in upper unconsolidated material where slight disturbance can initiate slope failure even on very gentle slopes. However, the failure of the individual slope is a complex mix of a variety of processes such as lithology, hydrology, structures, weathering rates, relief, slope angle, and its curvature. There seems to be no clear relation between landslide size and slope angle for rainfall-triggered landslides (Fig. 12). This points to an important understanding that either large or small landslide is not confined to a particular range of slope angles. Kasai and Yamada (2019) working on FAD of earthquake-triggered landslides observed that the probability density of landslides was highest in the range of $25^{\circ}-30^{\circ}$ and that landslide size increased up to $20^{\circ}-25^{\circ}$ slope angle, decreasing on further increase in slope angle. It can be seen in Fig. 12 that the median landslide size is almost equal for all groups of slope angles and therefore slope angle merely controls the number of landslides rather than landslide size. Interestingly, a greater number of largest landslides were observed in the slope range of $30^{\circ}-70^{\circ}$ (larger landslides, $0.05 \mathrm{~km}^{2}$ are few) followed by a few larger landslides on a very gentle slope $\left(<20^{\circ}\right)$. Steeper slopes $\left(>70^{\circ}\right)$ and slope range between $20^{\circ}-30^{\circ}$ seem to be devoid of larger landslides. Around $89 \%$ of the landslide area lies between $30^{\circ}-70^{\circ}$ slope angles, which shows that these slope angles are the most vulnerable zones. Landslides are observed along all slope directions in the analyzed basin albeit in different proportions (data of slope angle extracted from Aspect Map pf the basin) (Fig. 13). The percentage of landslides in the north-facing slope (NW to NE) is less in comparison to other directions. Around $50 \%$ of the landslide occurred on the 
landslide are confined to $E$ and $W$ direction (Fig,14). Similarly, 91\% of the landslide occur in the drainage density range of 1.2 to $2.1 \mathrm{~km} / \mathrm{km}^{2}$ while landslides show very low occurrence in either lower (< 1.2) or higher (>2.1) drainage density (Fig. 15). The total number of landslides analyzed is 2757 with a maximum, minimum, and average area of $0.24 \mathrm{~km}^{2}, 4 \times 10^{-6} \mathrm{~km}^{2}$, and $3.4 \times 10^{-3} \mathrm{~km}^{2}$, respectively. The landslide data superimposed over rainfall map clearly highlights the critical locations of landslides. Rainfall triggered landslide are very frequent and most widespread across the world. It has been noted that majority of rainfall induced landslide start as small and shallow failures but may transform to debris flow on its way down slope and increase the ultimate volume of the failed mass resulting into severe loss and damage (Crosta and Frattini 2003). The shallow nature of rainfall induced landslides is mainly attributed to sudden increase in pore pressure of the unconsolidated overburden causing the failure surface to develop with the soil profile or only in surficial layers in case of bedrock (Singh et al. 2017, Crosta, 1998). The probability-size distribution for landslides is generally similar universally with major differences in the rollover, cutoff point, and scaling exponent. Globally, authors have either analyzed FAD for a single triggering event such as earthquake, rainfall, etc. or landslides have been analyzed for multiple events, and all follow a similar trend for medium and large-scale landslides with the tail showing inverse power law fit. The scaling exponent of the tail for medium and large scale landslide is quite variable but a value of $-2.3 \pm 0.6$ seems the best fit for a large number of studies with a maximum reported over 3.0 (Brardinoni and Church 2004; Malamud et al. 2004; Catani et al. 2005; Eeckhaut et al. 2007). However, it is to be noted that smaller values have also been reported by many authors (Hovius et al. 1997; Stark and Hovius 2001; Martin et al. 2002; Hurst et al. 2013). The position of rollover (peak of FAD curve) in the FAD of this study is questionable as data of smaller landslide seems to be missing from the inventory but from the visual inspection, the peak seems to be achieved for the analyzed landslide data at around $50 \mathrm{~m}^{2}$. The cutoff point for the analyzed inventory is around $3000 \mathrm{~m}^{2}$, a point beyond which most of the data of medium and large landslide decays following an inverse power law with a scaling exponent of 2.3 (Fig. 16). Guthrie and Evans (2004) analyzing the magnitude-frequency relationship of a landslide triggered by a storm event suggested that proper characterization of magnitude-frequency of a landslide is necessary for the determination of impact, landscape denudation, and assessment of total risk.

\section{Conclusions}

The characteristic drainage patterns, observations from morphotectonic analysis, seismic activities in the Yamuna river basin confirms neotectonic activities in the basin. The ongoing upliftment of the basin, tilting, Active Mountain fronts, V-shaped valleys along with strong field evidences are some of the prominent signatures which confirm the ongoing active tectonics. The observation of the morphotectonic analysis landslide activities in the region suggests the role of active tectonics in modifying the landscape and shows good correlation with analysed landslide. Landslide characteristics were studied with the help of statistical analysis in the form of FAD plots and controls of different geomorphological parameters such as slope angle, slope direction, drainage density on the frequency of landslides. larger landslides are 
density below $2.2 \mathrm{~km}$ per square $\mathrm{km}$. The analysis reveals that landslides occur on a wide range of slope angles but the frequency of landslide $(\sim 78 \%)$ is greatest in the range of $40-70$. Interestingly, the slope angle merely controls the frequency of landslide, the size of landslide seems to have no clear relation with slope angle as the median size of landslide area shows only slight variation with slope angle. Both frequency and large landslides are either very less or absent at higher slope angles (> 70). Landslides can be seen in all slope directions but the south-facing slope (SW to SE) seems to have around $50 \%$ of the landslide in the basin and therefore most critical. For the analyzed rainfall-induced landslide inventory, the cutoff point is found at $3000 \mathrm{~m}^{2}$ beyond which inverse power law fits well for medium and large scale landslides with a scaling exponent of -2.3. From further analysis of FAD plots, it seems the data of small landslides is not complete in the inventory and therefore it becomes difficult to obtain the rollover. But from visual inspection, it seems that the peak of the FAD plot is at $50 \mathrm{~m}^{2}$, which can possibly be the rollover after which small landslides follow a positive power-law relationship.

\section{Declarations}

\section{Acknowledgment}

Authors appreciate the support and help by local individuals of Study area during the field survey. Authors thankfully acknowledge supports provided by Geological Survey of India "BHUKOSH" for providing data.

\section{References}

Ahmad, T., Harris, N., Bickel, M., Chapman, H., Bunbury, J., Prince, C., 2000. Isotopic constraints on the structural relationships between the lesser Himalayan series and the high Himalayan crystalline series, Garhwal Himalaya. Geological Society of America Bulletin, Vol. 112, pp. 467-477.

Awasthi, A.K., Prakash, S. (2001) Basin morphometry and landslide potential along Bhagirathi River valley in a part of Uttarkashi District, Garhwal Himalaya, Uttaranchal State (India). Journal of Indian Association of Sedimentologists, Vol 20(1), pp. 39-50.

Bennett GL, Molnar P, Eisenbeiss H, Mcardell BW (2012) Erosional power in the Swiss Alps:

Characterization of slope failure in the Illgraben. Earth Surf Process Landforms 37:1627-1640. doi: 10.1002/esp.3263.

Bishop, M. P. (2013). 3.1 Remote Sensing and GIScience in Geomorphology: Introduction and Overview. Treatise on Geomorphology, 1-24. doi:10.1016/b978-0-12-374739-6.00040-3

Brardinoni F, Church M (2004) Representing The Landslide Magnitude - Frequency Relation: Capilano River Basin , British Columbia. Earth Surf Process Landforms 29:115-124. doi: 10.1002/esp.1029

Bull WB (1978) Geomorphic Tectonic Classes of the South Front of the San Gabriel Mountains, California. U.S. Geoloaical Survev Contract Report. 14-08-001-G-394, Office of Earthquakes, Volcanoes and Loading [MathJax]/jax/output/CommonHTML/jax.js 
Engineering, Menlo Park, CA.

Bull WB, McFadden LD (1977) Tectonic geomorphology north and south of the Garlock Fault, California. Proceedings of the Eighth Annual Geomorphology Symposium, in: Geomorphology in Arid Regions, Doehring, D. O., (Ed), State University of New York, Binghamton 115-138.

Cerri, R.I., Reis, F.A.G.V., Gramani, M.F. et al. (2018) Assessment of landslide occurrences in Serra do Mar mountain range using kinematic analyses. Environ Earth Sci 77, 325. https://doi.org/10.1007/s12665018-7508-1

Chorley RJ (1957a) Climate and morphometry. J Geol 65:628-638

Chorley RJ (1957b) Climate and geomorphology. J Geol 65(6):628-638

Chorley RJ (1969) The drainage basin as the fundamental geomor- phic unit. In: Chorley RJ (ed) Introduction to fluvial processes. Methuen

Chorley RJ, Morgan MA (1962) Comparison of morphometric features, Unaka Mountains, Tennessee and North Carolina, and Dartmoor, England. Geol Soc Am Bull 73:17-34

Cox RT (1994) Analysis of drainage-basin symmetry as a rapid technique to identify areas of possible Quaternary tilt-block tectonics: an example from the Mississippi Embayment. Geological Society of America Bulletin, Vol. 106(5), pp. 571-581.

Crosta G, Frattini P (2003) Distributed modelling of shallow landslides triggered by intense rainfall. Nat Hazards Earth Syst Sci 3(1-2):81-93

Crosta G.(1998) Rainfall threshold regionalization: an aid for landslide susceptibility zonation. Environmental Geology, 35(2-3), pp. 131-145

Cruden DM (1991) A Simple Definition of a Landslide. Bull Int Assoc Eng Geol 43:27-29

Cruden DM, Varnes DJ (1996) Landlides Types and Processes. In: Landslides: Investigation and Mitigation, Transportation Research Board Special Report 247, Washington D.C. pp 36-75

Das, Sujit and Gupta, Krishnendu (2019) Morphotectonic analysis of the sali river basin, bankura district, West Bengal, Arabian Journal of Geosciences, Vol. 12(7), pp. 244

Daxberger, H., Dalumpines, R., Scott, D. M., and Riller, U. (2014) “The ValleyMorph Tool: An automated extraction tool for transverse topographic symmetry (T-) factor and valley width to valley height (Vf-) ratio",Computers and Geosciences, vol. 70, pp. 154-163.

Eeckhaut M Van Den, Poesen J, Govers G, et al (2007) Characteristics of the size distribution of recent and historical landslides in a populated hilly region. Earth Planet Sci Lett 256:588-603. doi: 
Florsheim JL, Nichols A (2013) Catena Landslide area probability density function statistics to assess historical landslide magnitude and frequency in coastal California CA. Catena 109:129-138. doi: 10.1016/j.catena.2013.04.005

Gaidzik K, Ramírez-Herrera MT (2017) Geomorphic indices and relative tectonic uplift in the Guerrero sector of the Mexican forearc. Geoscience Frontiers 8(4): 885-902.

Gardiner V (1996) Channel networks: progress in the study of spatial and temporal variations of drainage density. In: Gurnell A, Petts GE (eds) Changing river channels. Wiley, New York, pp 65-85

Guarnieri, Pierpaolo, Pirrotta, Claudia, (2007). The response of drainage basins to the late Quaternary tectonics in the Sicilian side of the Messina Strait (NE Sicily), Geomorphology, Vol. 95 (3-4), pp. 260-273.

Guthrie RH, Evans SG (2004) Magnitude and frequency of landslides triggered by a storm event , Loughborough Inlet, British Columbia. Nat Hazards Earth Syst Sci 4:475-483

Guzzetti F, Ardizzone F, Cardinali M, et al (2009) Landslide volumes and landslide mobilization rates in Umbria , central Italy. Earth Planet Sci Lett 279:222-229. doi: 10.1016/j.epsl.2009.01.005

Guzzetti F, Malamud BD, Turcotte DL, Reichenbach P (2002) Power-law correlations of landslide areas in central Italy. Earth Planet Sci Lett 195:169-183

HACK, J.T. (1973) Stream-profile analysis and stream-gradient index: U.S. Geological Survey. Journal Research, v. 1, n. 4, p. 421-429.

Hare, P.W. and Gardner, T.W. (1985). Geomorphic indicators of vertical neotectonism along converging plate margins, Nicoya Peninsula, Costa Rica. In: Morisawa, M., Hack, J.T. (Eds.), Tectonic Geomorphology. Proceedings of the 15th Annual Binghamton Geomorphology Symposium. Allen and Unwin, Boston, MA, pp. 123-134.

Hasegawa, S., Nonomura, A., Nakai, S., and Dahal, R. K. (2013) Drainage Density as Rainfall Induced Landslides Susceptibility Index in Small Catchment Area, Vol. 1(1), pp. 27-28

Horton RE (1945) Erosional development of streams and their drainage basins: hydrophysical approach to quantitative morphology. Bull Geol Soc Am 56:275-370.

Horton, R.E. (1932), Drainage Basin Characteristics, Transactions of American Geophysical. Union, 13, pp 350-361

Hovius N, Stark CP, Allen PA (1997) Sediment flux from a mountain belt derived by landslide mapping. Geology 25:231-234. doi: 10.1130/0091-7613(1997)025<0231:SFFAMB>2.3.C0;2

Hungr O, Leroueil S, Picarelli L (2014) The Varnes classification of landslide types, an update. Landslides

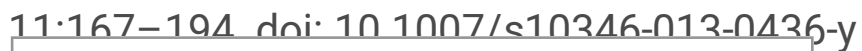

Loading [MathJax]/jax/output/CommonHTML/jax.js

Page 13/33 
Hurst MD, Ellis MA, Royse KR, et al (2013) Controls on the magnitude-frequency scaling of an inventory of secular landslides. Earth Surf Dyn 1:67-78. doi: 10.5194/esurf-1-67-2013

Jain V, Sinha R (2005) Response of active tectonics on the alluvial Baghmati river, Himalayan foreland basin, eastern India. Geomorphology Vol. 70, pp. 339-356

Kale, V.S., Shejwalkar, N. (2008) Uplift along the western margin of the Deccan Basalt Province: Is there any geomorphometric evidence?. J Earth Syst Sci 117, 959-971

Kasai M, Yamada T (2019) Topographic effects on frequency - size distribution of landslides triggered by the Hokkaido Eastern Iburi Earthquake in 2018. Earth, Planets Sp 8:. doi: 10.1186/s40623-019-1069-8

Keller E.A. and Pinter N. (2002) - Active Tectonics. Earthquakes, Uplift, and Landscape. Prentice Hall, New Jersey, $362 \mathrm{pp}$

Keller EA (1986) Investigation of active tectonics: use of surficial earth processes. In: Wallace, R.E. (Ed.), Active Tectonics, Studies in Geophysics. National Academy Press, Washington, DC. pp. 136-147

Korup, O. (2005). Distribution of landslides in southwest New Zealand. Landslides, 2(1), 43-51. doi:10.1007/s10346-004-0042-0

Kumar, M. (2016). Tectonic and Exhumation History of the Almora Nappe, South-Eastern Kumaun Lesser Himalaya, Uttarakhand (India), Ph.D. thesis, Dept. of Geology, Kumaun University, Nainital, Uttarakhand India.

Larsen MC, Torres-sanchez AJ (1998) The frequency and distribution of recent landslides in three. Geomorphology 24:309-331

Li C, Ma T, Zhu X, Li W (2011) The power-law relationship between landslide occurrence and rainfall level. Geomorphology 130:221-229. doi: 10.1016/j.geomorph.2011.03.018

Malamud BD, Turcotte DL, Guzzetti F, Reichenbach P (2004) Landslide inventories and their statistical properties. Earth Surf Process Landforms 29:687-711. doi: 10.1002/esp.1064

Martin Y, Rood K, Schwab JW, Church M (2002) Sediment transfer by shallow landsliding in the Queen Charlotte Islands, British Columbia. Can J Earth Sci 39:189-205. doi: 10.1139/e01-068

Melton MA (1957) An analysis of the relations among elements of cli- mate, surface, properties and geomorphology. Project NR 389-042 Technical Report 11. Columbia University, Department of Geology, ONR, Geography Branch, New York

Mesa LM (2006) Morphometric analysis of a subtropical Andean basin (Tucuman, Argentina). J Environ Geol, Vol. 50(8), pp. 1235-1242 
Miller VC (1953) A quantitative geomorphologic study of drainage basin characteristics in the Clinch Mountain area, Virginia and Tennessee, Project NR 389042, Tech Report 3. Columbia University Department of Geology, ONR Geography Branch, New York

Morisawa ME (1962) Quantitative Geomorphology of some watersheds in the Appalachian Plateau. Geol Soc Am Bull 73:1025-1046

Prabhakaran, A. and Jawahar Raj, N. (2018) Drainage morphometric analysis for assessing form and processes of the watersheds of Pachamalai hills and its adjoinings, Central Tamil Nadu, India, Vol. 8 (1), pp. 1-19

Prabhakaran, A. Jawahar Raj, N. (2018) Drainage morphometric analysis for assessing form and processes of the watersheds of Pachamalai hills and its adjoinings, Central Tamil Nadu, India, Applied Water Science, Vol. 8, pp.31.

Queiroz, G. L. Salamuni, E. Nascimento, E. R. (2015) Knickpoint finder: A software tool that improves neotectonic analysis, Computers and Geosciences, Vol. 76, pp.80-87.

Rai, Praveen Kumar, Mohan, Kshitij, Mishra, Sameer, Ahmad, Aariz, Mishra, Varun Narayan (2017) A GISbased approach in drainage morphometric analysis of Kanhar River Basin, India, Applied Water Science, Vol. 7 (1), pp. 217-232

Rana N, Singh S, Sundriyal Y P, Rawat G S and Juyal N 2016 Interpreting the geomorphometric indices for neotectonic implications: An example of Alaknanda valley, Garhwal Himalaya, India; J. Earth. Syst. Sci. 125(4) 1-14.

Rockwell, T.K., Keller, E.A., Johnson, D.L., 1985. Tectonic geomorphology of alluvial fans and mountain fronts near Ventura, California. In: Morisawa, M. (Ed.), Tectonic Geomorphology. Proceedings of the 15th Annual Geomorphology Symposium. Allen and Unwin Publishers, Boston, MA, pp. 183-207

Seybold, H., Berghuijs W.R., Prancevic, J.P., Kirchner, J.W. (2020) Global dominance of tectonics over climate in shaping river longitudinal profile, A preprint submitted to EarthArXiv, pp. 1-10.

Shankar, R., Singh, A.K., Satyam, G. P., and Heidi Daxberger (2020) Active tectonics Influences in the Satluj River basin in and around Rampur, Himachal Himalaya, India. Arabian Journal of Geosciences 13(14):624

Sharp, R.P. (1982) Landscape Evolution (A Review). Proceedings of the National Academy of Sciences of the United States of America, 79, pp. 4477-4486

Silva, P.G., Goy, J.L., Zazo, C., Bardajm, T., 2003. Fault generated mountain fronts in Southeast Spain: geomorphologic assessment of tectonic and earthquake activity. Gemorphology, Vol. 250, pp. 203-226. 
Singh PK, Kainthola A, Singh TN (2015a) Earthquake-induced rockfall along cut slopes - a case study. EUROCK 64th Geomech. Colloquium Schubert Kluckner, pp. 1127-1132.

Sreedevi PD, Subrahmanyam K, Shakeel A (2005) The significance of morphometric analysis for obtaining groundwater potential zones in a structurally controlled terrain. J Environ Geol 47(3):412-420

Stark CP, Hovius N (2001) The characterization of landslide size distribution. Geophys Res Lett 28:10911094

Strahler AN (1956) Quantitative slope analy - sis. Geol Soc Am Bull 67(5):571-596.

Tanyas H, Westen CJ Van, Allstadt KE, Jibson RW (2019) Factors controlling landslide frequency - area distributions. Earth Surf Process 44:900-917. doi: 10.1002/esp.4543

Troiani, F., Galve, J. P., Piacentini, D., Della Seta, M., \& Guerrero, J. (2014). Spatial analysis of stream length-gradient (SL) index for detecting hillslope processes: A case of the Gállego River headwaters (Central Pyrenees, Spain). Geomorphology, 214, 183-197. doi:10.1016/j.geomorph.2014.02.004

Valdiya K. S. (2010). The Making of Indian Geodynamic Evolution. Macmillian Publication House India, pp. 816.

Valdiya, K. S. (2016). The Making of India. Society of Earth Scientists Series. doi:10.1007/978-3-31925029-8.

Valdiya, K.S., 1980. Geology of Kumaun Lesser Himalaya. Wadia Institute of Himalayan Geology, Dehra Dun, India, p. 291.

Valdiya, K.S., Joshi, D.D., Sanwal, R. and Tandon, S.K. (1984) Jour. Geol. Soc. India, v.25, pp.761-774

Varnes DJ (1978) Slope movement types and processes. In: Landslides: Analysis and Control, Transportation Research Board Special Report, 176, Washington, DC. pp 11-33

Wilson JS, Chandrasekar N, Magesh NS (2012) Morphometric analysis of major Sub Watersheds in Aiyar \& Karai Pottanar Basin, Central Tamil Nadu, India using Remote Sensing \& GIS Techniques. Bonfring Int J Ind Eng Manag Sci, Vol. 2(special issue 1), pp. 8-15

Yin A 2006 Cenozoic tectonic evolution of the Himalayan orogen as constrained by along-strike variation of structural geometry, exhumation history, and foreland sedi- mentation; Earth-Sci. Rev. Vol. 76, pp. 1131.

Zavoianu I (1985) Morphometry of drainage basins. Elsevier, Amster- dam, pp 238

\section{Tables}

Loading [MathJax]/jax/output/CommonHTML/jax.js ; analysed in the present study

Page 16/33 


\begin{tabular}{|l|l|}
\hline Total basin area & $16653.56 \mathrm{~km}^{2}$ \\
\hline Total number of landslides & 2757 \\
\hline Total Landslide area & $9.215 \mathrm{~km}^{2}$ \\
\hline Largest landslide & $0.24 \mathrm{~km}^{2}$ \\
\hline Smallest landslide & $4 \times 10^{-7} \mathrm{~km}^{2}$ \\
\hline Mean landslide area & $3.334 \times 10^{-3} \mathrm{~km}^{2}$ \\
\hline Median landslide area & $8 \times 10^{-4} \mathrm{~km}^{2}$ \\
\hline Standard deviation of landslide area & $1.38 \times 10^{-2} \mathrm{~km}^{2}$ \\
\hline
\end{tabular}

\section{Table 1 List of morphotectonic parameters used in the present study}

\begin{tabular}{|c|c|c|c|c|}
\hline $\begin{array}{l}\text { S. } \\
\text { no. }\end{array}$ & $\begin{array}{l}\text { Morphotectonic } \\
\text { Indices }\end{array}$ & $\begin{array}{l}\text { Mathematical } \\
\text { Derivations }\end{array}$ & Description & Reference \\
\hline 1. & Drainage density & $\mathrm{D}_{\mathrm{d}}=\mathrm{L}_{\mathrm{u}} / \mathrm{A}$ & $\begin{array}{l}\mathrm{D}_{\mathrm{d}}=\text { drainage density, } \\
\mathrm{L}_{\mathrm{u}}=\text { total stream length of all } \\
\text { orders, } \\
\mathrm{A}=\text { area of the basin }(\mathrm{km} 2)\end{array}$ & $\begin{array}{l}\text { Chorley } \\
1957\end{array}$ \\
\hline 2 . & Form Factor $\left(F_{f}\right)$ & $\mathrm{F}_{\mathrm{f}}=\mathrm{A} / \mathrm{L}_{\mathrm{b}}^{2}$ & $\begin{array}{l}\mathrm{F}_{\mathrm{f}}=\text { Form factor } \\
\mathrm{A}=\text { Aarea of the Basin }\left(\mathrm{km}^{2}\right) \\
\mathrm{L}_{\mathrm{b}}=\text { basin length }(\mathrm{km})\end{array}$ & $\begin{array}{l}\text { Horton, } \\
1932\end{array}$ \\
\hline 3. & $\begin{array}{ll}\text { Circulatory ratio } \\
\text { (Rc) }\end{array}$ & $\mathrm{Rc}=4 \Pi \mathrm{A} / \mathrm{P}^{2}$ & $\begin{array}{l}\text { RC=circularity ratio, } \\
\Pi=3.14 \\
A=\text { area of the basin }\left(\mathrm{km}^{2}\right) \\
P=\text { perimeter }(\mathrm{km})\end{array}$ & Miller, 1953 \\
\hline 4. & $\begin{array}{lr}\text { Stream } & \text { Length } \\
\text { Gradient } & \text { Index } \\
\text { (SL) } & \end{array}$ & $\begin{array}{c}\mathrm{SL}=(\Delta \mathrm{H} / \\
\Delta \mathrm{L}) \times \mathrm{L}\end{array}$ & $\begin{array}{l}\Delta \mathrm{H}=\text { Change in elevation of the } \\
\text { streams } \\
\Delta \mathrm{L}=\text { Change in length of the } \\
\text { channel } \\
\mathrm{L}=\text { Total length of the channel }\end{array}$ & Hack, 1973 \\
\hline $5 .$. & $\begin{array}{ll}\text { Asymmetry } & \text { factor } \\
\text { (AF) } & \end{array}$ & $\begin{aligned} A F & =\left(A_{r} / A_{t}\right) \\
& \times 100\end{aligned}$ & $\begin{array}{l}\text { AR = Area of the basin to the right } \\
\text { (facing downstream) } \\
\mathrm{AT}=\text { The total area of the drainage } \\
\text { basin }\end{array}$ & $\begin{array}{l}\text { Hare and } \\
\text { Gardner, } \\
1985\end{array}$ \\
\hline 6. & $\begin{array}{l}\text { Transverse } \\
\text { Topographic } \\
\text { Symmetry (T) }\end{array}$ & $\mathrm{T}=\mathrm{D}_{\mathrm{a}} / \mathrm{D}_{\mathrm{d}}$ & $\begin{array}{l}\mathrm{D}_{\mathrm{a}}=\text { Distance from midline of the } \\
\text { drainage basin to the midline of the } \\
\text { active meander belt. } \\
\mathrm{D}_{\mathrm{d}}=\text { Distance from the basin } \\
\text { midline to basin divide. }\end{array}$ & Cox (1994) \\
\hline 7. & $\begin{array}{l}\text { Mountain Front } \\
\text { Sinuosity }\left(\mathrm{S}_{\mathrm{mf}}\right)\end{array}$ & $\mathrm{S}_{\mathrm{mf}}=\mathrm{L}_{\mathrm{mf}} / \mathrm{L}_{\mathrm{s}}$ & $\begin{array}{l}\mathrm{L}_{\mathrm{mf}}=\text { The topographic break in the } \\
\text { slope } \\
\mathrm{Ls}=\text { Length of the mountain front } \\
\text { measured along the straight line }\end{array}$ & $\begin{array}{l}\text { (Bull and } \\
\text { McFadden } \\
1977\end{array}$ \\
\hline
\end{tabular}




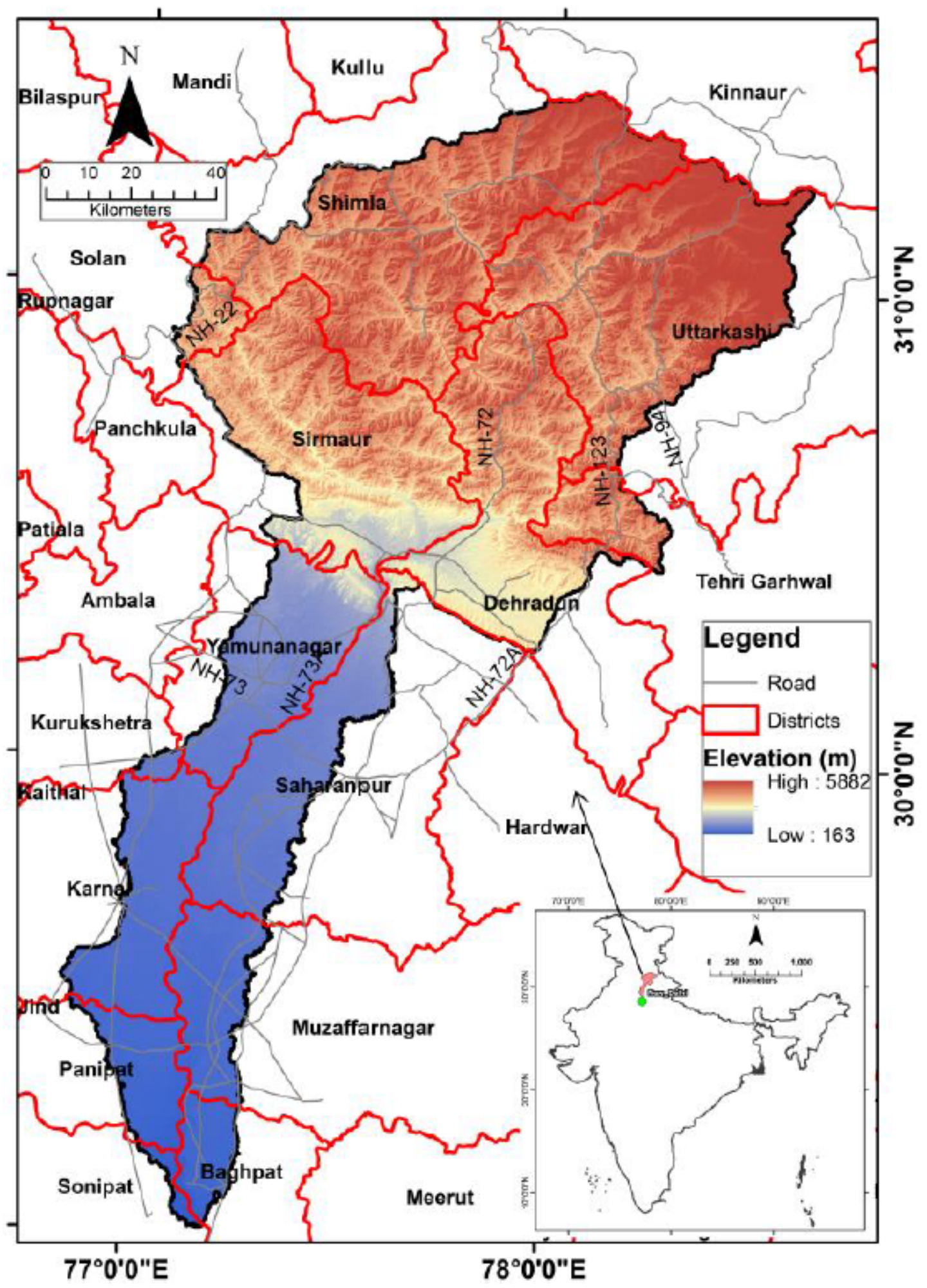

Figure 1

The ASTER DEM of the Yamuna River basin showing elevations and major locations, highways and railways. Note: The designations employed and the presentation of the material on this map do not imply the expression of any opinion whatsoever on the part of Research Square concerning the legal status of any country, territory, city or area or of its authorities, or concerning the delimitation of its frontiers or Loading [MathJax]/jax/output/CommonHTML/jax.js the authors. 


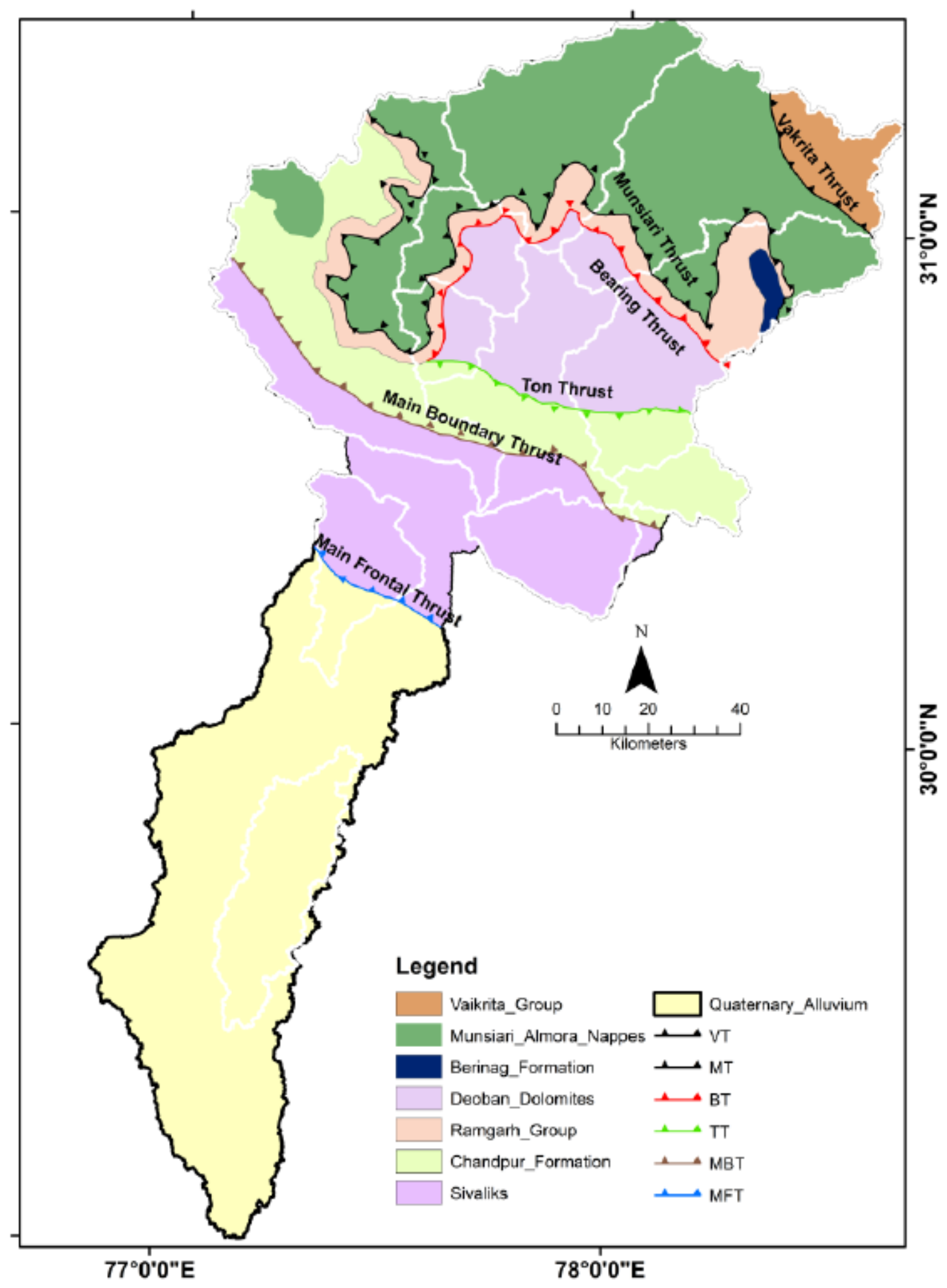

Figure 2

The regional map of Yamuna River basin along with major geological Formations (Modified after Valdiya 1980) (white lines indicates sub-basin boundary). Note: The designations employed and the presentation of the material on this map do not imply the expression of any opinion whatsoever on the part of Research Square concerning the legal status of any country, territory, city or area or of its authorities, or Loading [MathJax]/jax/output/CommonHTML/jax.js r boundaries. This map has been provided by the authors. 


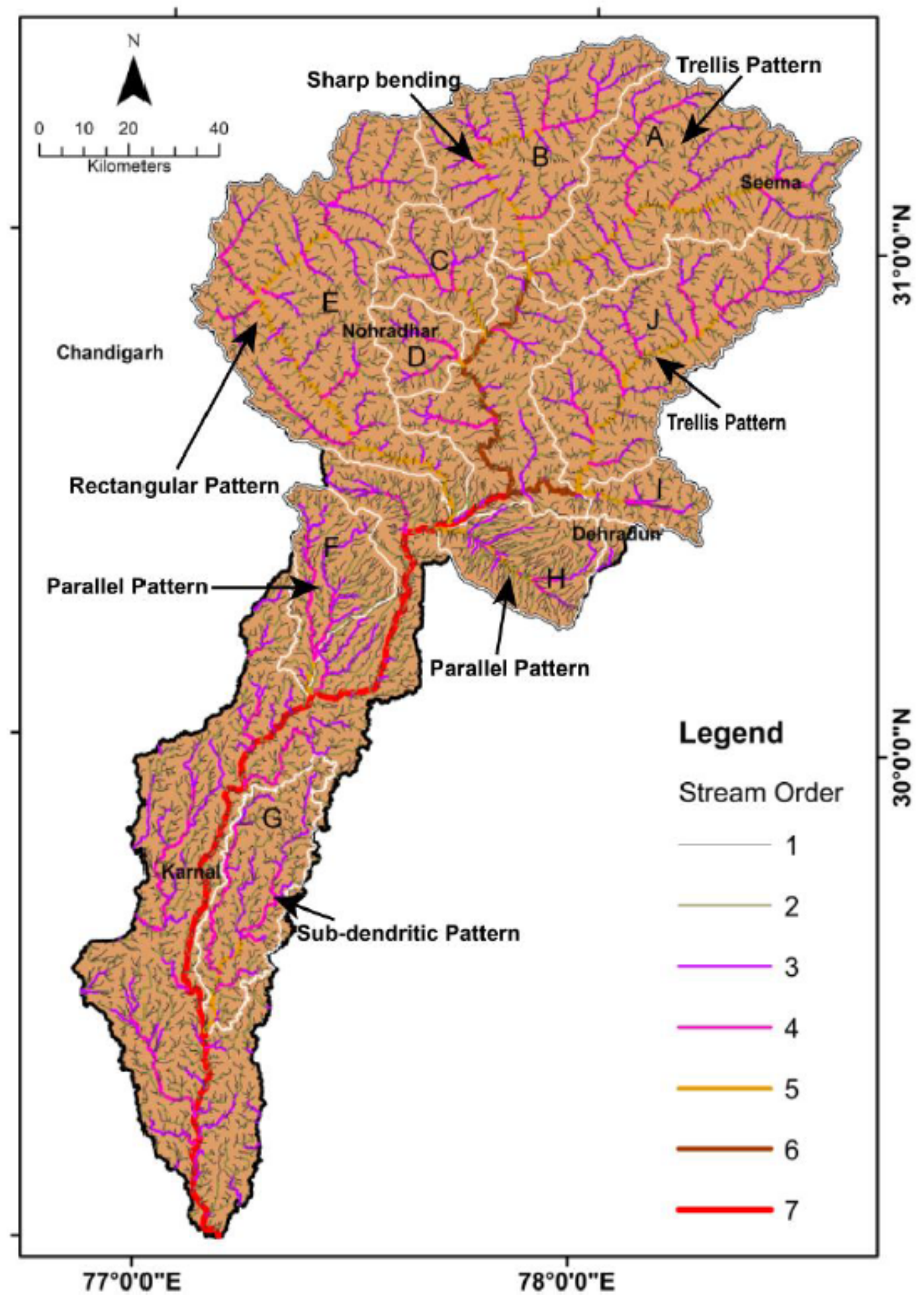

Figure 3

Drainage basin map showing selected 5 th order sub-basins (A to $\mathrm{J}$ ) showing different drainage patterns, Note: The designations employed and the presentation of the material on this map do not imply the expression of any opinion whatsoever on the part of Research Square concerning the legal status of any country, territory, city or area or of its authorities, or concerning the delimitation of its frontiers or 


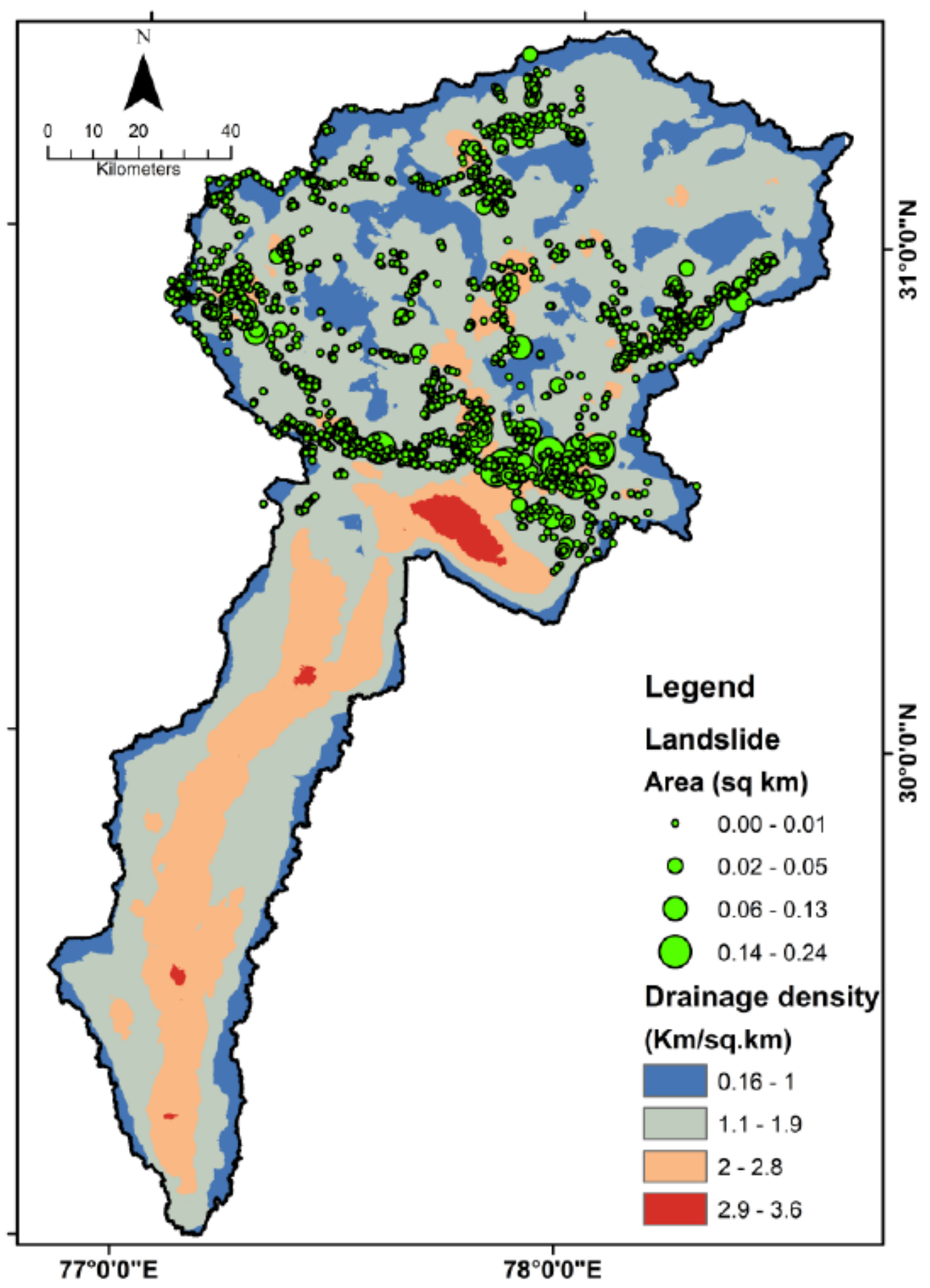

Figure 4

Drainage basin map showing selected 5 th order sub-basins (A to $\mathrm{J}$ ) showing different drainage patterns. Note: The designations employed and the presentation of the material on this map do not imply the expression of any opinion whatsoever on the part of Research Square concerning the legal status of any country, territory, city or area or of its authorities, or concerning the delimitation of its frontiers or 


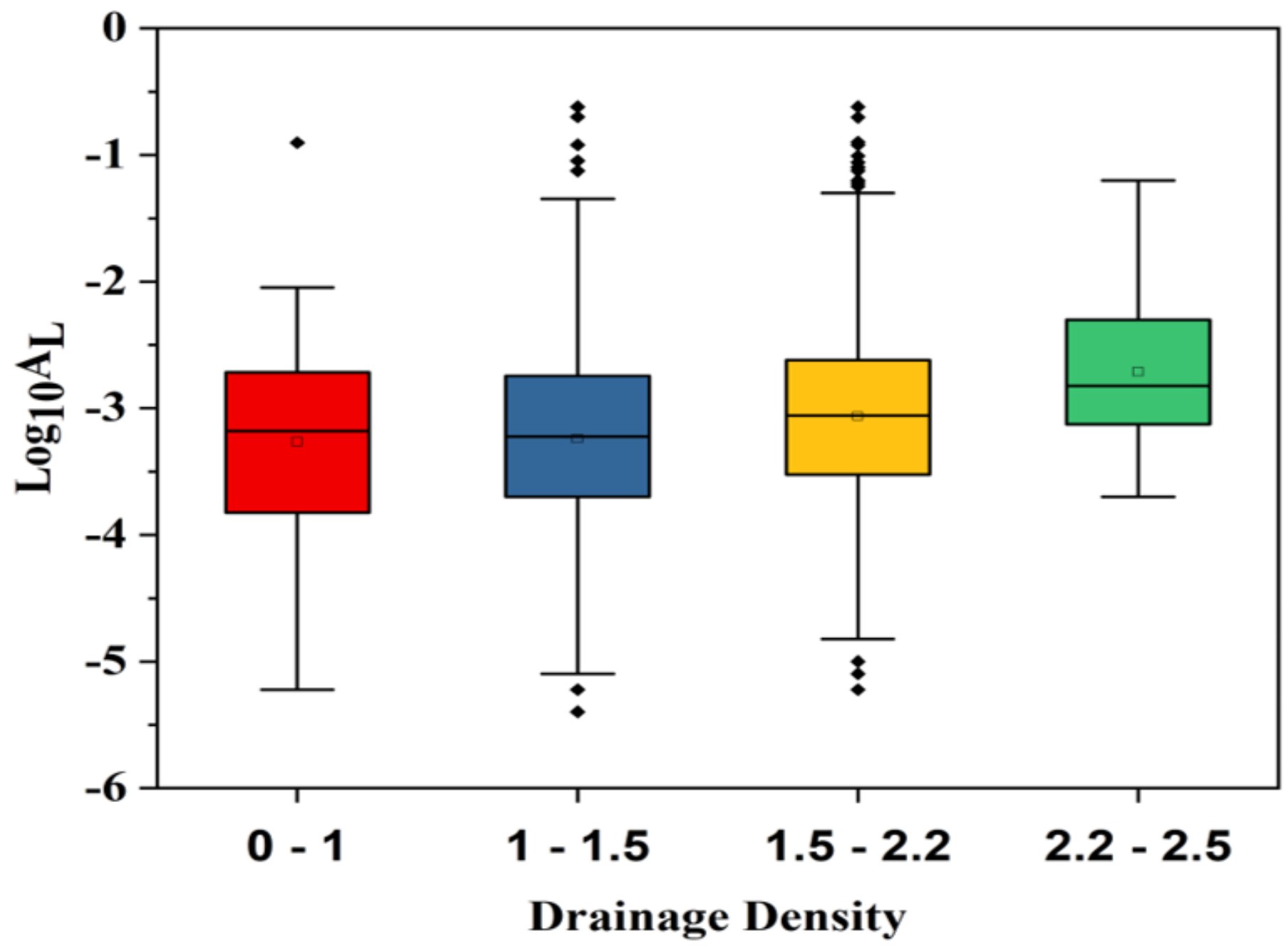

Figure 5

Plot between Landslide area and drainage density of Yamuna River basin North Western Himalaya, India 

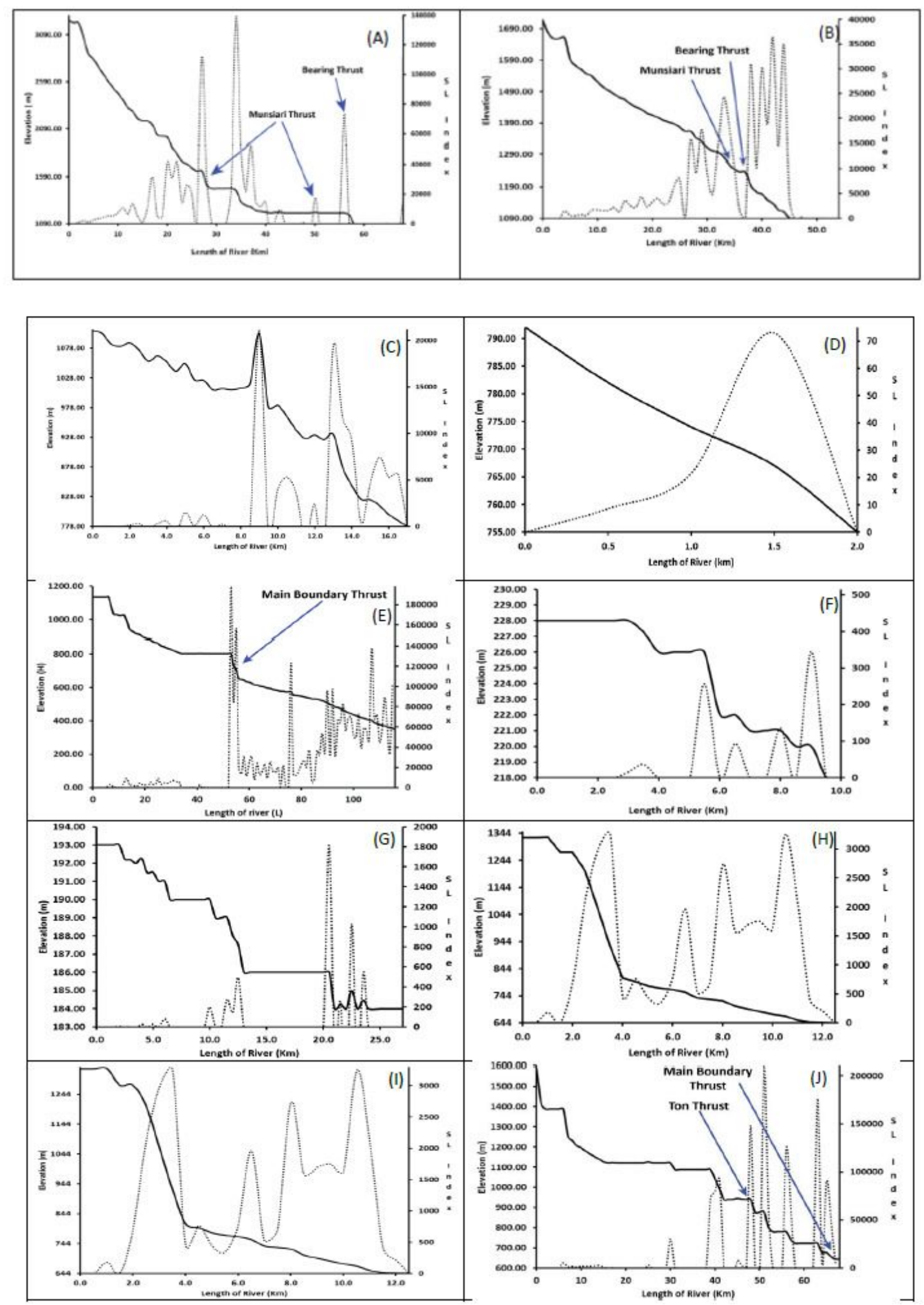

Figure 6

The SL curve (dotted line) for the 5th-order drainage basins (A to J) of the Yamuna river basin, North Western Himalaya, India (longitudinal river profile represented by the solid line). 


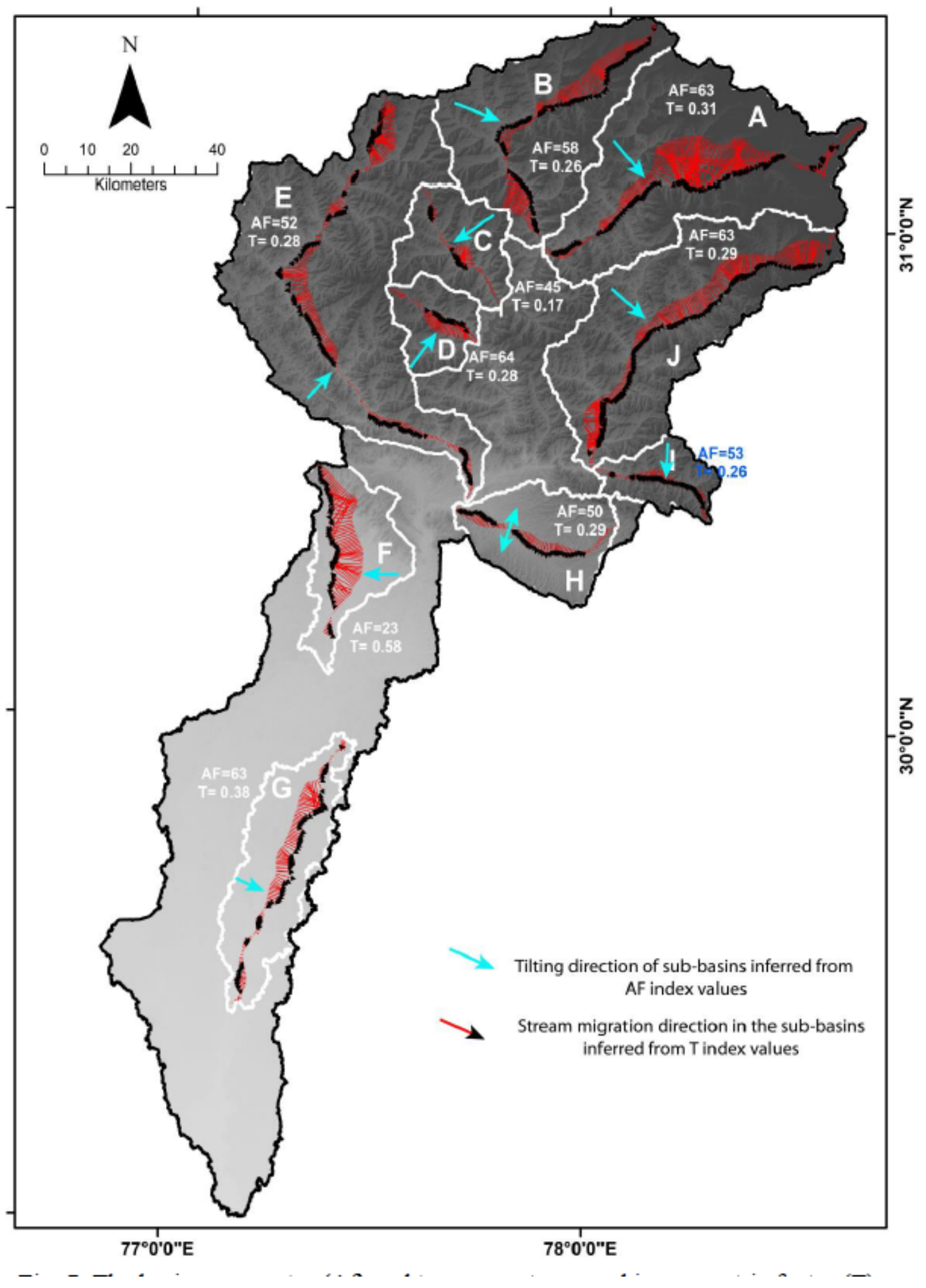

Figure 7

The basin asymmetry (Af) and transverse topographic symmetric factor ( $T$ ) vector showing stream migration direction and tilt directions (indicated by black and red-black arrows) of Yamuna river basin , North Western Himalaya, India. Note: The designations employed and the presentation of the material on this map do not imply the expression of any opinion whatsoever on the part of Research Square 
concerning the legal status of any country, territory, city or area or of its authorities, or concerning the delimitation of its frontiers or boundaries. This map has been provided by the authors.

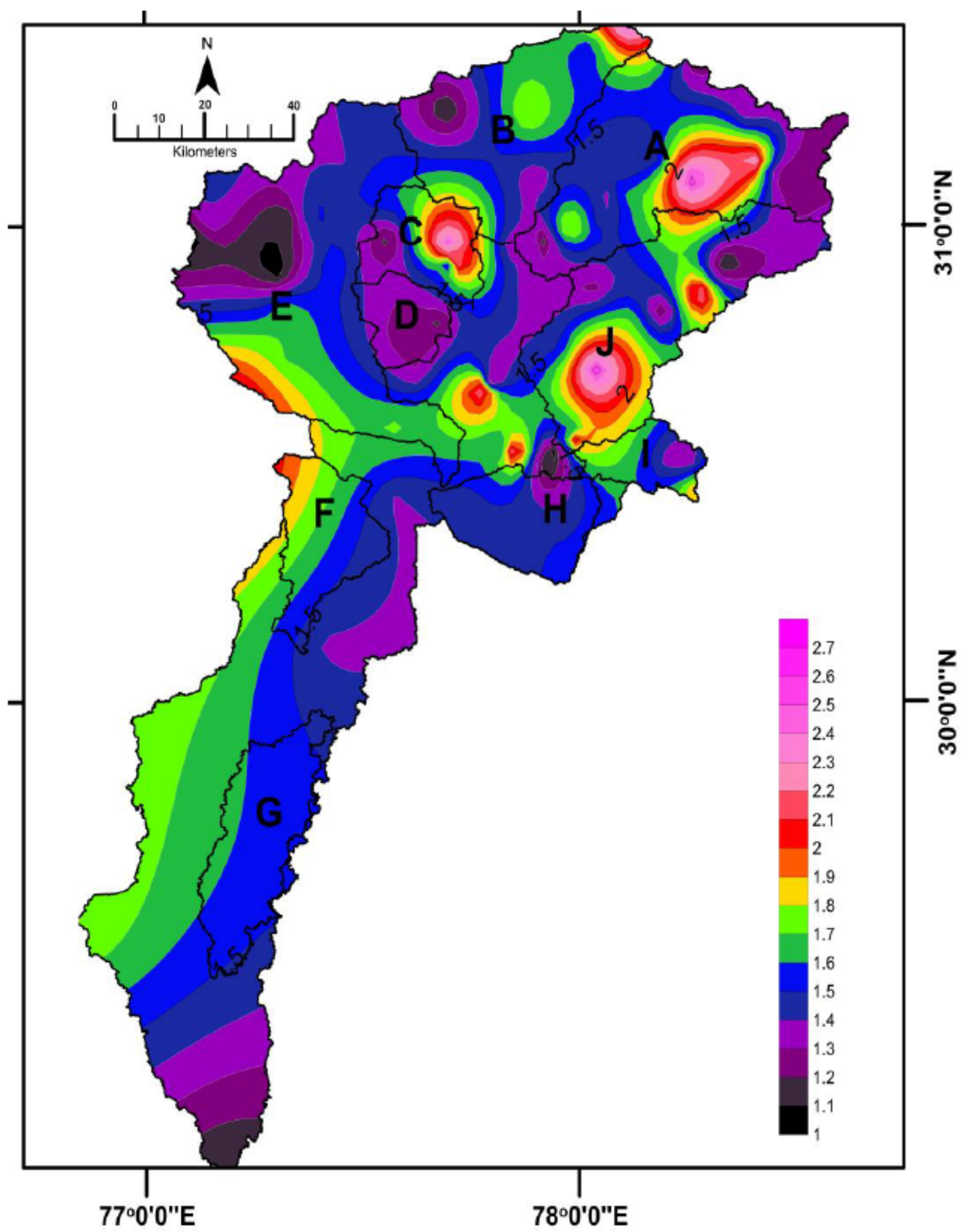

Figure 8

The Smf map of the Yamuna River basin North Western Himalaya, India. Note: The designations employed and the presentation of the material on this map do not imply the expression of any opinion Loading [MathJax]/jax/output/CommonHTML/jax.js concerning the legal status of any country, territory, city or 
area or of its authorities, or concerning the delimitation of its frontiers or boundaries. This map has been provided by the authors.

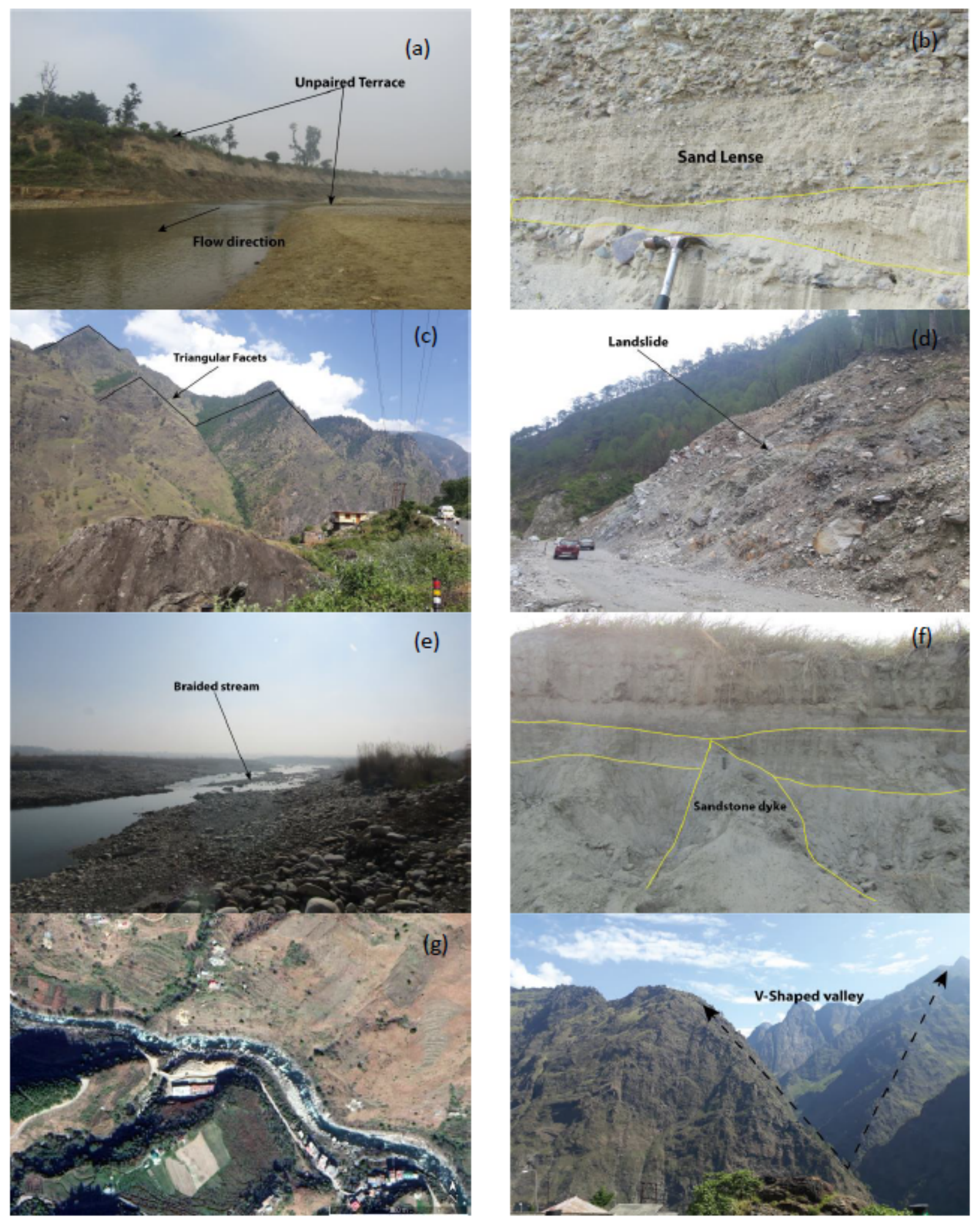

\section{Figure 9}

Field evidence of active tectonics (a) unpaired terrace at Yamunanagar in Haryana (b) sand lense Tajewala near Mohand ridge in Haryana (c) triangular fault facets at Purola (d) active landslide near Loading [MathJax]/jax/output/CommonHTML/jax.js ) sandstone dyke near Gyasuddin pur (taken from google 
earth) (g) knick points Himachal Pradesh (h) V shaped valley near Tyaan village (taken from google earth)

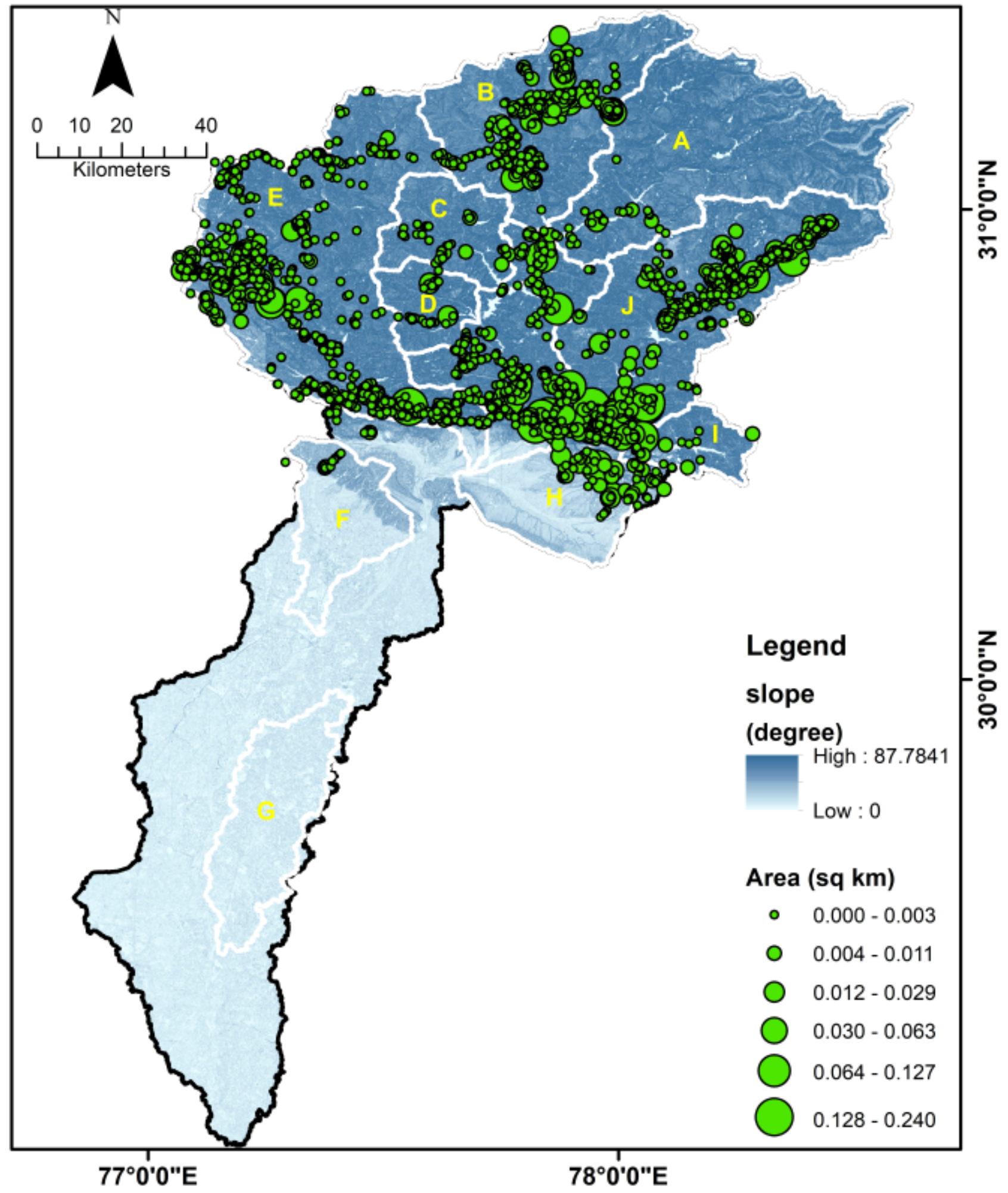

Figure 10

The slope map of the of the Yamuna River basin showing distribution of slope in, North Western Himalaya, India. (The data of magnitude and landslides data have been taken http://bhukosh.gsi.gov.in/) Loading [MathJax]/jax/output/CommonHTML/jax.js esentation of the material on this map do not imply the 
expression of any opinion whatsoever on the part of Research Square concerning the legal status of any country, territory, city or area or of its authorities, or concerning the delimitation of its frontiers or boundaries. This map has been provided by the authors.

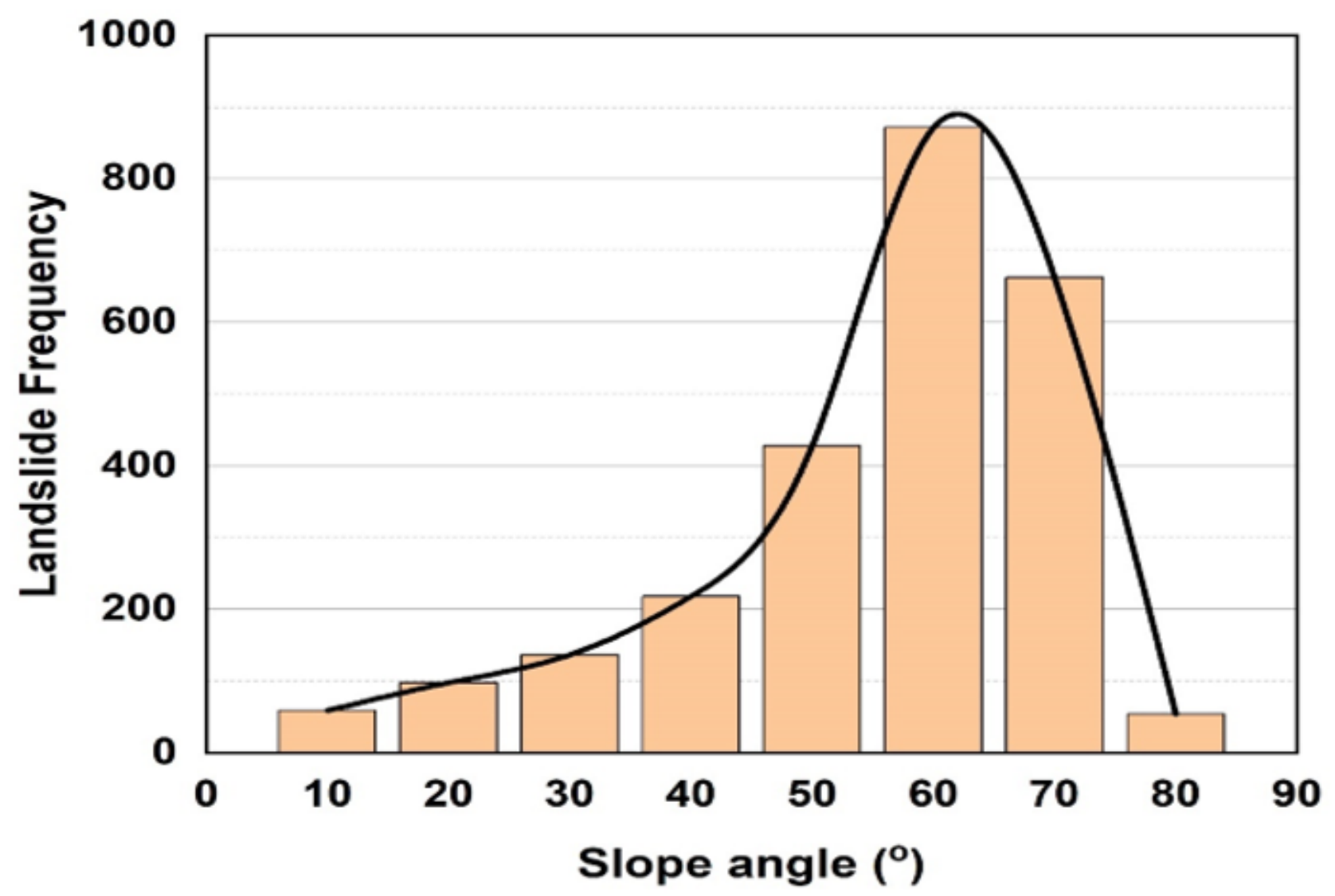

Figure 11

Landslide frequency versus slope angle plot of Yamuna River basin North Western Himalaya, India. 


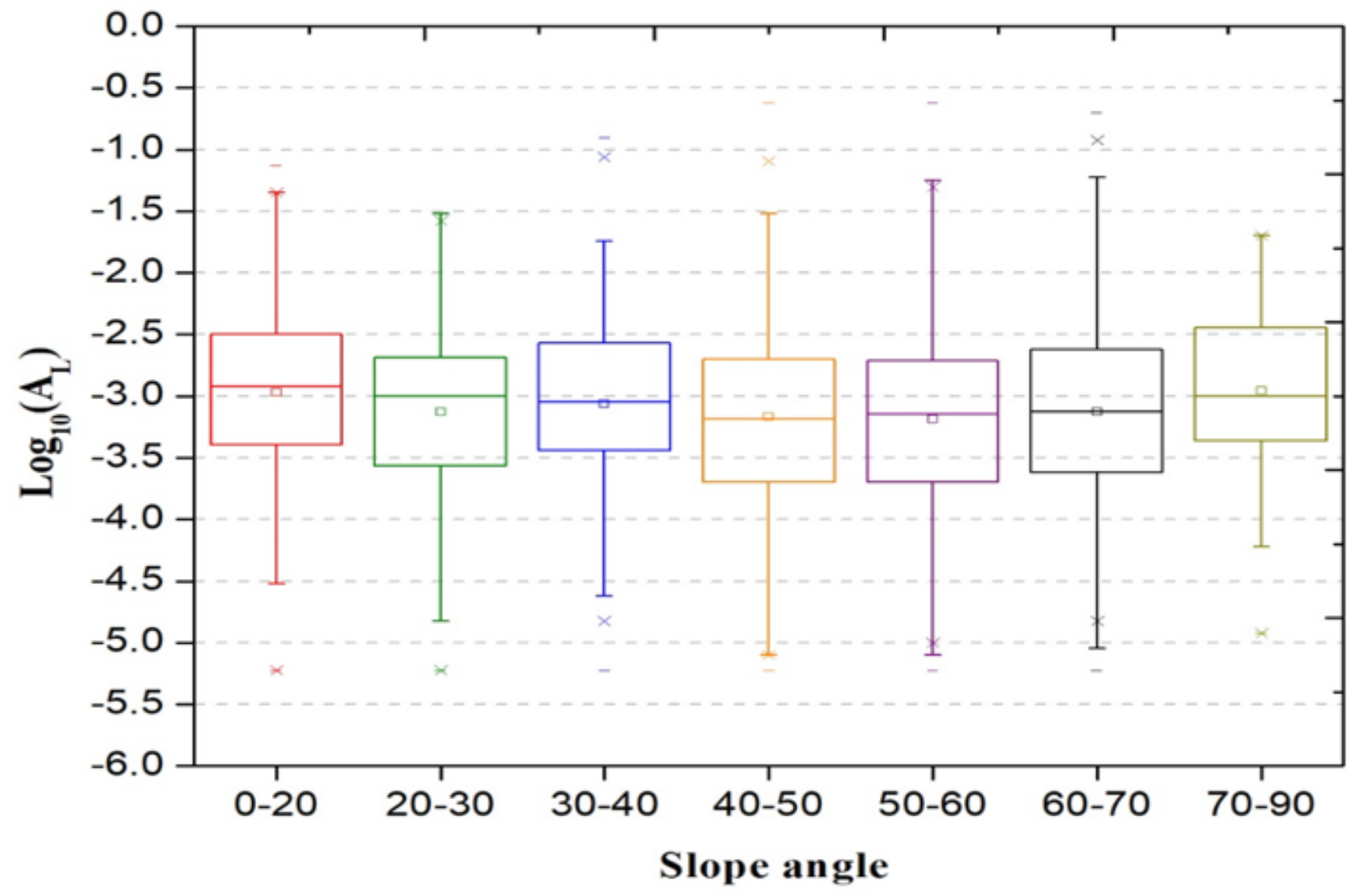

Figure 12

Landslide area versus slope angle plot of Yamuna River basin North Western Himalaya, India 


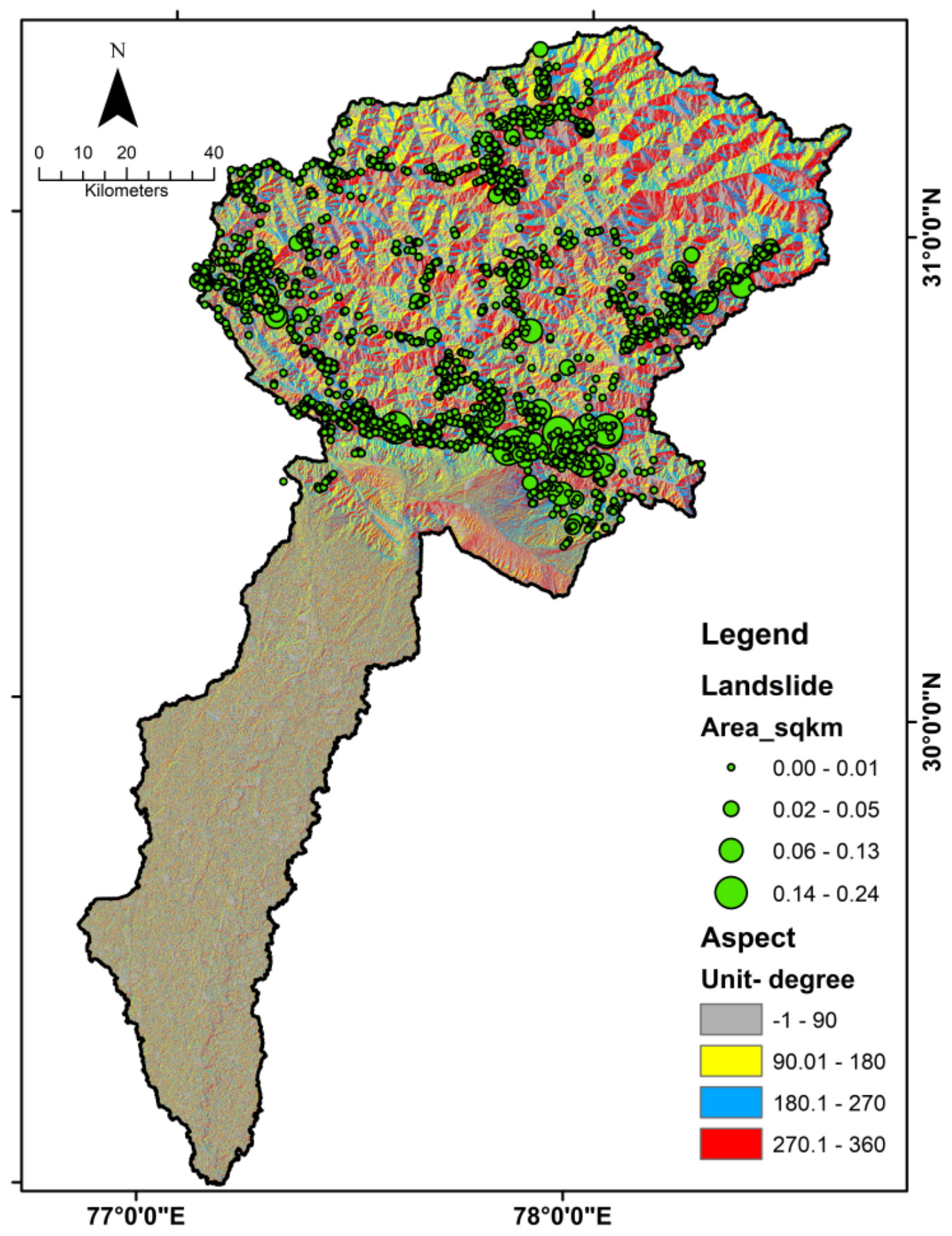

Figure 13

The Aspect map of the Yamuna River basin North Western Himalaya, India. Note: The designations employed and the presentation of the material on this map do not imply the expression of any opinion whatsoever on the part of Research Square concerning the legal status of any country, territory, city or area or of its authorities, or concerning the delimitation of its frontiers or boundaries. This map has been 


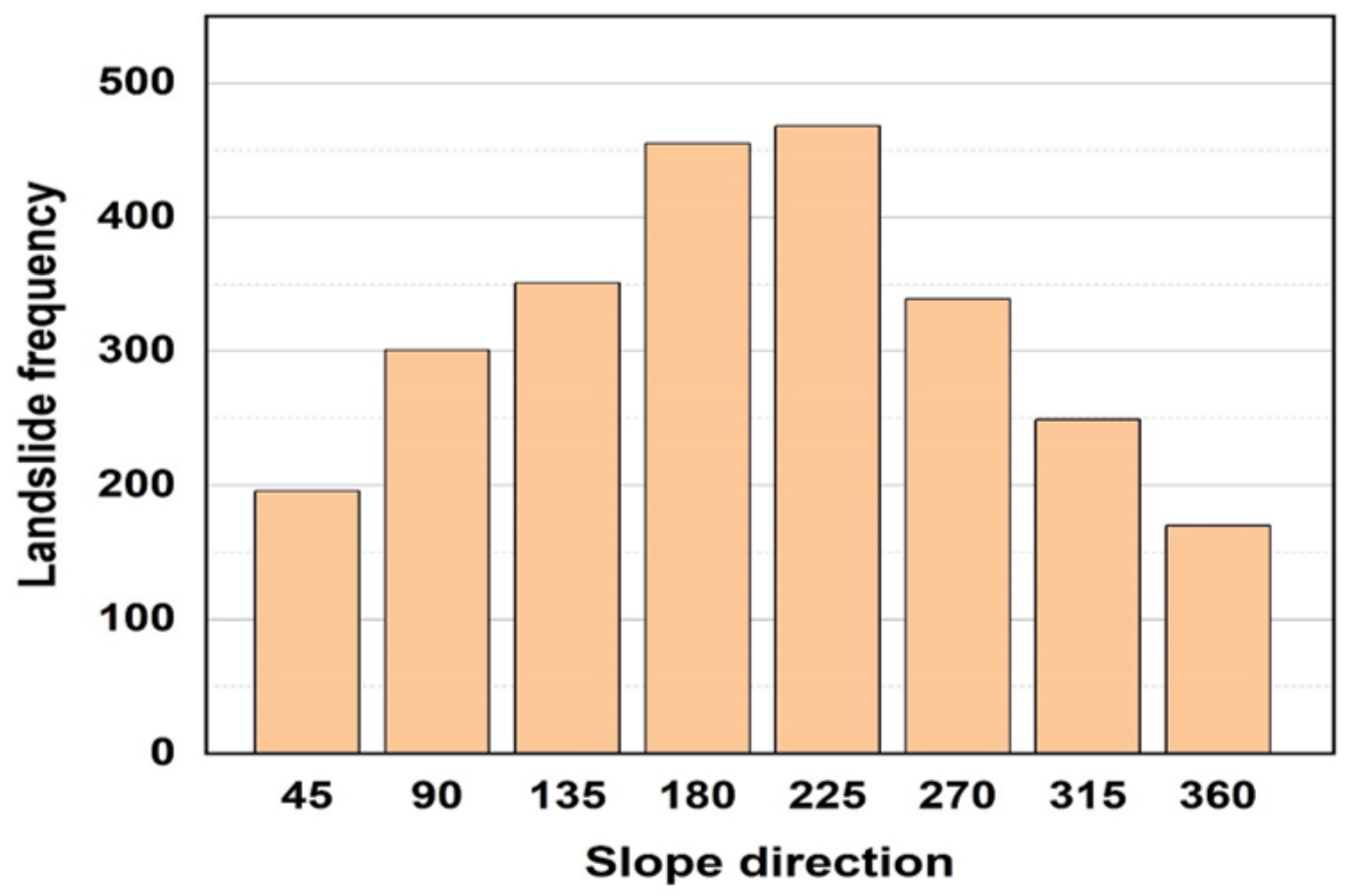

Figure 14

Landslide frequency versus slope direction plot of Yamuna River basin North Western Himalaya, India 


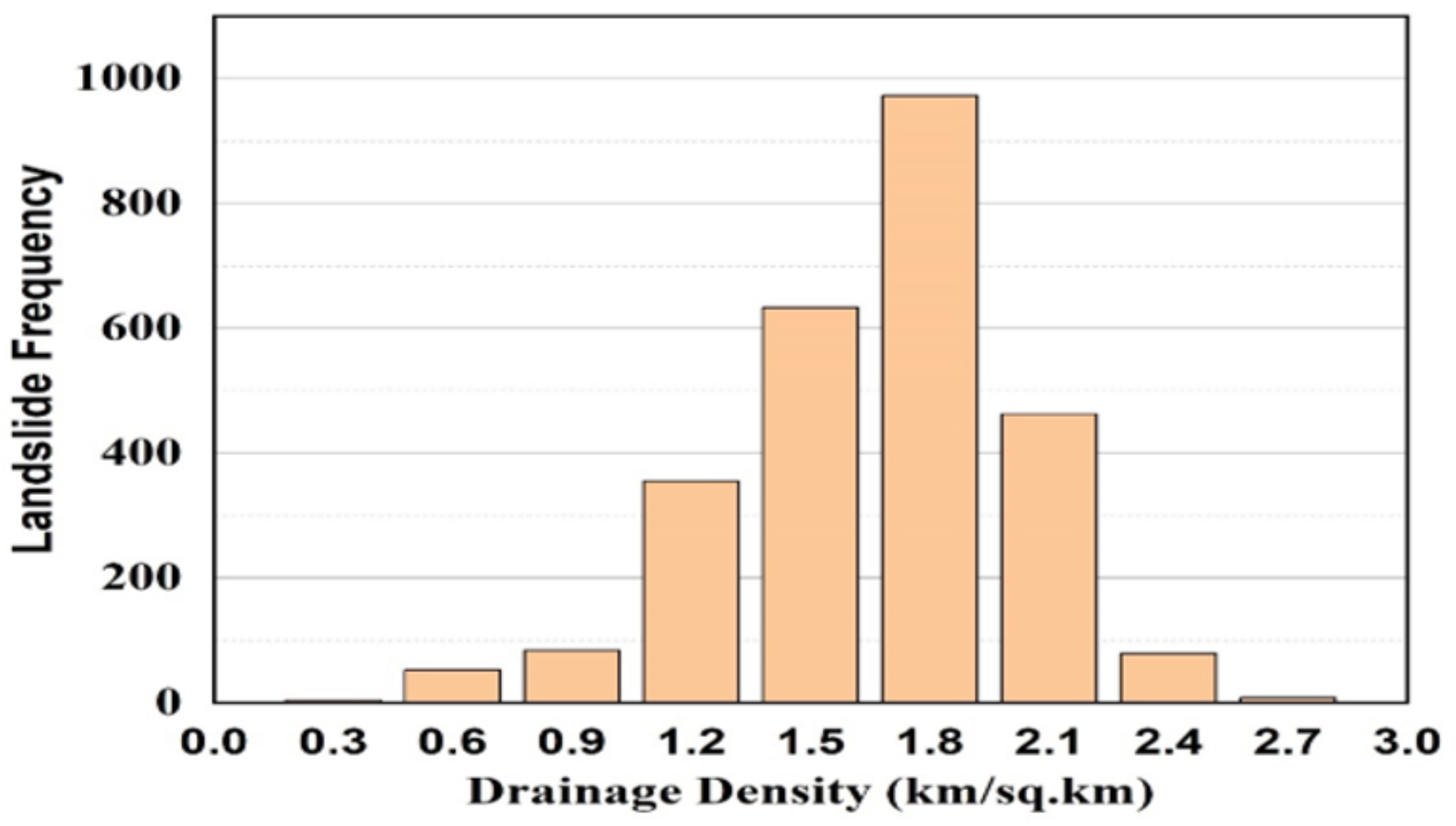

Figure 15

Landslide frequency versus drainage density plot of Yamuna River basin North Western Himalaya, India

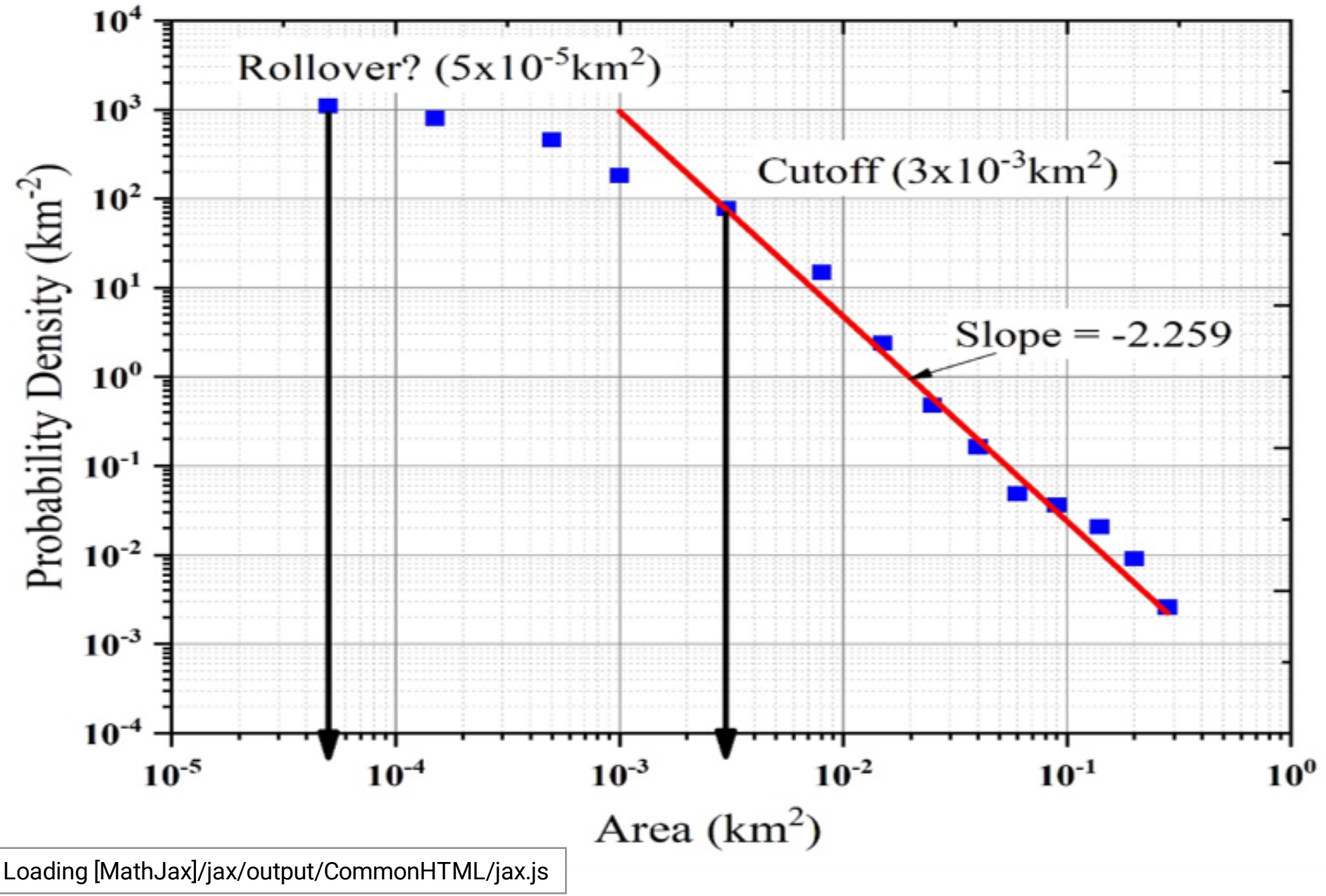


Figure 16

Landslide probability density distribution versus area plot of Yamuna River basin North Western Himalaya, India 